\title{
DEVELOPING MYANMAR'S INFORMATION AND COMMUNICATION TECHNOLOGY SECTOR TOWARD INCLUSIVE GROWTH
}

Kee-Yung Nam, Maria Rowena Cham, and Paulo Rodelio Halili

NO. 462

November 2015
ADB ECONOMICS WORKING PAPER SERIES 
ADB Economics Working Paper Series

\section{Developing Myanmar's Information and Communication Technology Sector toward Inclusive Growth}

Kee-Yung Nam, Maria Rowena Cham, and Paulo Rodelio Halili

No. 462 | November 2015
Kee-Yung Nam (kynam@adb.org) is Principal Economist, Maria Rowena Cham (rmcham@adb.org) is Senior Economics Officer, and Paulo Rodelio Halili (phalili@adb.org) is Senior Economics Officer at the Economic Research and Regional Cooperation Department, Asian Development Bank (ADB).

This paper was written as a background paper for the ADB Myanmar Country Diagnostics Study. The authors wish to thank Ron Ico and Lotis Quiao for their excellent research support. 
Asian Development Bank

6 ADB Avenue, Mandaluyong City

1550 Metro Manila, Philippines

www.adb.org

(C) 2015 by Asian Development Bank

November 2015

ISSN 2313-6537 (Print), 2313-6545 (e-ISSN)

Publication Stock No. WPS157751-2

The views expressed in this paper are those of the authors and do not necessarily reflect the views and policies of the Asian Development Bank (ADB) or its Board of Governors or the governments they represent.

ADB does not guarantee the accuracy of the data included in this publication and accepts no responsibility for any consequence of their use.

By making any designation of or reference to a particular territory or geographic area, or by using the term "country" in this document, $A D B$ does not intend to make any judgments as to the legal or other status of any territory or area.

Notes:

1. In this publication, " $\$$ " refers to US dollars.

2. ADB recognizes "Korea" as the Republic of Korea and "Burma" as Myanmar.

The ADB Economics Working Paper Series is a forum for stimulating discussion and eliciting feedback on ongoing and recently completed research and policy studies undertaken by the Asian Development Bank (ADB) staff, consultants, or resource persons. The series deals with key economic and development problems, particularly those facing the Asia and Pacific region; as well as conceptual, analytical, or methodological issues relating to project/program economic analysis, and statistical data and measurement. The series aims to enhance the knowledge on Asia's development and policy challenges; strengthen analytical rigor and quality of ADB's country partnership strategies, and its subregional and country operations; and improve the quality and availability of statistical data and development indicators for monitoring development effectiveness.

The ADB Economics Working Paper Series is a quick-disseminating, informal publication whose titles could subsequently be revised for publication as articles in professional journals or chapters in books. The series is maintained by the Economic Research and Regional Cooperation Department. 


\section{CONTENTS}

TABLES AND FIGURES $\quad v$

ABSTRACT vi

$\begin{array}{ll}\text { I. INTRODUCTION } & 1\end{array}$

II. POLICY FRAMEWORK AT THE REGIONAL AND NATIONAL LEVELS 2

III. LEGAL AND REGULATORY FRAMEWORK 4

IV. $\quad$ REGULATORY POLICY BY SPECIFIC AREA 6

A. $\quad$ Competitive Markets 6

B. Ownership $\quad 7$

C. Licensing 8

D. Spectrum Management 8

E. Infrastructure Sharing and Interconnection 9

F. Voice over Internet Protocol 10

G. Universal Access and Service 10

V. INSTITUTIONAL FRAMEWORK 11

VI. CURRENT STATE OF INFORMATION AND COMMUNICATION TECHNOLOGY 12

$\begin{array}{ll}\text { A. Accessibility } & 12 \\ \text { B. } & 17\end{array}$

B. $\quad$ Affordability and Price Controls 17

VII. BEYOND INFORMATION AND COMMUNICATION TECHNOLOGY INFRASTRUCTURE: HUMAN DEVELOPMENT, INDUSTRIES, E-GOVERNANCE 18

A. Human Development 18

B. Information and Communication Technology Industries 20

C. Information and Communication Technology as an Enabler in Public Services:

e-Governance 20

VIII. INFORMATION AND COMMUNICATION TECHNOLOGY SECTOR CONSTRAINTS 21

A. Absence of a Separate and Independent Regulator 22

B. Inadequate Information and Communication Technology Legal Framework and Implementing Guidelines $\quad 22$

C. $\quad$ Limited Foreign Investment 22

D. Inadequate Physical Infrastructure to Support Information and Communication Technology Investments 23

E. Skills Gap and Mismatch in Information and Communication Technology 23 
IX. RECOMMENDATIONS

APPENDIX

REFERENCES 


\section{TABLES AND FIGURES}

\section{TABLES}

$1 \quad$ Level of Competition in Southeast Asia's ICT Sector, 2014

$2 \quad$ Foreign Ownership in ICT Sector in Southeast Asia 8

3 Technical Summary of Myanmar ICT Infrastructure 13

4 Penetration and Usage Rates of ICT Services 13

$5 \quad$ Quality of Internet Service 16

6 Percentage of Population with Access to ICT Services 17

\section{FIGURES}

$1 \quad$ Organization Structure of the MCIT

2 Investment in Telecommunications Services

3 Indicators of Computer Education in Higher Education Institutes in Myanmar, 1995-2011 


\begin{abstract}
Myanmar's recent socioeconomic and political reforms have signaled a readiness to reintegrate into the world economy. To leapfrog the economy and accelerate growth, the country should take advantage of digital technology. This paper assesses Myanmar's information and communication technology sector, identifies constraints the sector faces, and recommends policies that will help the government overcome them. Given limited public resources, Myanmar will need help translating its information and communication technology infrastructure needs into financially viable and bankable projects that can attract private sector financing.
\end{abstract}

Keywords: e-governance, ICT infrastructure, information and communication technology development, Myanmar, telecommunications

JEL Classification: L86, L88, L96, L98 


\section{INTRODUCTION}

Information and communication technology (ICT) infrastructure has been developing steadily in countries around the world. Yet, despite generally wide ICT coverage in major cities, levels in rural areas is far from satisfactory; indeed, many people there still have no ICT access. Differences in income, population size, and geography have created a digital divide between urban and rural areas, especially in Asia's developing economies. At the regional level, one would think that a sizable population anywhere in Asia would have access to mobile connections or fixed telephone lines. But the numbers paint a completely different picture, with large subregional and subnational disparities.

For many decades, fixed lines delivered telecommunication services, which are reliable and fairly easy to expand. They are, however, expensive and require more time to install. Installation of fixed lines has expanded mostly in major cities and highly populated areas, with high installation costs and geographical barriers in rural areas inhibiting installation and complicating maintenance of physical infrastructure such as cables.

Wireless technology has provided alternative telecommunications access to rural and remote areas. It can cover a wide range of areas without using cables and its equipment is relatively easy to install. The increased use of wireless technology is helping to expand access to ICT in the rural areas of developing economies, especially when basic infrastructure such as a trunk connection is already in place. Although ICT coverage in rural areas in these economies has expanded significantly, poor commercial viability has hindered expansion in sparsely populated and remote areas. New and emerging technologies can broaden coverage and penetrate any area. But the digital divide will not be completely addressed as long as governments fail to overcome the various socioeconomic constraints that prohibit wider access to ICT services.

Myanmar has signaled its readiness to reintegrate with the world economy through recent socioeconomic and political reforms. These can enable Myanmar to achieve strong and sustainable economic growth and materially improve the lives of its people. Digital technology can enable the country to leapfrog the usual development track and further accelerate growth.

For now, Myanmar's internet, mobile, and telephone usage rates are Southeast Asia's lowest. Its ICT infrastructure is inadequate and the industry is still in its infancy. But there is huge potential for ICT development. And despite high upfront costs, the gains, in the form of higher productivity and more efficient delivery of public and private commercial services, could be considerable.

This paper assesses Myanmar's ICT sector, identifies the constraints, and offers policy options for the government to address them. In the rest of the paper, section II discusses the ICT policy framework at regional and national levels. Sections III and IV examine the legal and regulatory framework governing the ICT sector, particularly on competitive markets, ownership, licensing, spectrum management, infrastructure sharing and interconnection, internet surveillance, and universal access. Sections $\mathrm{V}$ and $\mathrm{VI}$ outline the institutional framework and accessibility and affordability of ICT in Myanmar. Section VII discusses the sector's human capital needs, the development of ICT-based businesses, and the state of e-governance in Myanmar. Section VIII summarizes the main findings on the constraints and section IX offers policy recommendations for the short- to medium-term to enable Myanmar's ICT sector to catch up with its Southeast Asian neighbors. 


\section{POLICY FRAMEWORK AT THE REGIONAL AND NATIONAL LEVELS}

Member countries of the Association of Southeast Asian Nations (ASEAN) are striving to become a single community by 2015, and ICT development is viewed as an important factor to facilitate integration, not only within member countries, but also within the region.

Spearheaded by the ASEAN Telecommunications and Information Technology Ministers, an ASEAN ICT Master Plan 2015 was formulated to harness ICT potential in establishing the ASEAN Economic Community. The master plan is a broad policy framework to guide ASEAN member states' ICT development over the next 5 years. The key outcomes of the master plan are to (i) develop ICT as an engine of growth for ASEAN countries, (ii) gain recognition for ASEAN as a global ICT hub, (iii) enhance the quality of life for the peoples of ASEAN, and (iv) contribute toward ASEAN integration. To achieve these key objectives, the plan formulates three foundations supporting three pillars. The foundations are infrastructure development, human capital development, and bridging the digital divide. The pillars are economic transformation, people empowerment and engagement, and innovation.

The development of Myanmar's ICT sector will certainly bring advantages, as increased access to information and communication will support the country's economic transformation after decades of military rule and international isolation. Studies show that investments in ICT, by improving productivity and connectivity, can spur growth. Investors are eyeing Myanmar opportunities as one of the last untapped markets in Asia, and its ICT sector has the potential to grow significantly after decades of underdevelopment.

Despite the country's growing population and market, however, the penetration rate of ICT services is the lowest in Southeast Asia. Mobile cellular subscribers were only 49.47 per 100 people in 2014, despite increasing some 50 -fold in the 6 years before that. This is far below mobile penetration rates per 100 people of Cambodia (155), Thailand (144), and Viet Nam (147) in 2014. And although fixed telephone subscriptions have increased by a factor of two since 1995, they are still only 0.98 subscription per 100 people, with an estimated base of 0.5 million subscribers. The internet user penetration rate is similarly low, at just over 1\%, according to 2013 data from the International Telecommunication Union (ITU).

Telecommunications services remain financially out of reach for the average Myanmar citizen. Call rates, for one thing, are high at an estimated $\$ 0.30$ per minute. And telecommunication-related infrastructure, as noted, has mostly favored urban areas.

The government has laid down the policy framework for developing the telecommunications and ICT industry by introducing competition for foreign and domestic operators. This is in line with its objective to foster overall economic development. The main objectives of the policy is increasing the country's mobile teledensity to $80 \%$ by FY2015 and making telecommunication services available to the general public at affordable prices, especially in rural areas.' Moreover, the government aims to allow citizens and private businesses to choose the telecommunication service that best suits their needs. This ambitious plan, which is needed if the country is to integrate into the global economy, will require billions of dollars in investments to improve network infrastructure and increase access, especially of the rural population.

1 FY refers to the fiscal year, which is from 1 April to 31 March in Myanmar. FY before a calendar year denotes the year in which the fiscal year starts, that is, FY2015 begins on 1 April 2015 and ends on 31 March 2016. 
As well as the need to build and update its ICT infrastructure, Myanmar needs to update, draft, and, in some cases, repeal laws governing the sector (in particular telecommunications and internet development and usage). It needs to set up a regulatory framework for the sector to ease investor uncertainty; indeed, the potential for ICT growth will be constrained if there is no clarity in regulations and the various processes for private sector participation.

Myanmar's telecommunication laws have been undergoing such changes to address these and other emerging issues the sector faces. The Ministry of Communications and Information Technology (MCIT) oversees the sector, but this institutional arrangement needs to be reviewed to ensure that its functions align with the sector's needs. More groundwork is needed for financing and implementing a network expansion and additional infrastructure requirements. If the government can adopt a stable regulatory framework, in addition to the various structural reforms it has been implementing, then Myanmar should be able to attract foreign investment to the ICT sector. This in turn can help the government achieve its growth and inclusiveness objectives for the economy.

Myanmar recognizes that ICT is a key enabler and a priority for socioeconomic development. The Framework for Economic and Social Reform, formulated in 2013, sets out policy priorities until 2016, and includes the development of mobile telephony and internet. The framework highlights the following ICT-related reform objectives:

(i) achieving $80 \%$ penetration services by 2015 ;

(ii) allowing for full sector liberalization by opening the ICT market to both foreign and domestic investors on a nondiscriminatory basis, implementing a regulatory system that can ensure effective competition among suppliers, and regulating tariffs;

(iii) upgrading internet infrastructure to allow a comprehensive e-strategy for leapfrogging in, among other areas, education programs, government regulation, and knowledge management; and

(iv) increasing the technical competence of the workforce through training on marketoriented technical and language skills.

The government has also identified the need to update its own ICT Master Plan to operationalize the reforms identified under the Framework for Economic and Social Reform. The development of an e-government national portal is ongoing, as is the creation of the bodies that will implement e-government plans. In 2013, a new Telecommunications Law was approved that aims to delineate the policy, regulatory, and operational functions of various stakeholders in the sector. Other related laws to support the development of the ICT sector are also being pursued as part of the country's ASEAN Economic Community commitments. These laws, once passed, will make Myanmar the fourth ASEAN nation to have ICT laws (Ministry of Communications, Posts, and Telegraphs, Korea International Cooperation Agency, and Electric and Telecommunications Research Institute 2011).

There have already been three previous ICT master plans: the 2000-2005 ICT Master Plan, the 2006-2010 ICT Master Plan and Action Plan, and the 2011-2015 Follow Up Plan. The first focused on expediting the implementation of ICT development plans and establishing physical infrastructure. This includes the Yatanarpon Cyber City opened in 2007, the country's largest IT center, Myanmar ICT Park, and Bagan International Data Communication Center and Teleport, both opened in 2001 (ITU 2012a). The 2006-2010 plan laid the foundations to achieve the goal of increasing the teledensity rate from 1\% in 2005 to $5.4 \%$ by 2011. Despite these well-laid plans, the ICT sector has not developed as expected. Sanctions, global recession, lack of prioritization in the ICT sector, sluggish firm 
performance, and heavy competition hamper the sector's development (Ministry of Communications, Posts, and Telegraphs, Korea International Cooperation Agency, and Electric and Telecommunications Research Institute 2011). The theme of the 2011-2015 Follow Up Plan (Ministry of Communications, Posts and Telegraphs, and Korea International Cooperation Agency 2011) was "socio-economic development through knowledge-based society." Its main objectives were enhancing the ability of citizens to use ICT, strengthening national competitiveness by promoting informatization, facilitating economic growth by promoting the ICT industry and establishing information infrastructure, and realizing good governance and clean government through ICT.

The plan has several focus areas including (i) building ICT infrastructure, ICT human resource development, and a legal framework for ICT; (ii) industry promotion, which covers the development of industry standards, and facilitating the liberalization of the industry; and (iii) use of ICT in eeducation, e-commerce, e-government, informatization, and e-society. These focus areas were grouped into five action plans-ICT infrastructure, ICT industry, ICT human resources development, e-education, and ICT legal framework. The action plans are to be implemented by various ministries and departments over the next 10 years.

The development of a broadband service has become an international focus of development partners and agencies engaged in Myanmar, including the ITU and the United Nations Educational, Scientific and Cultural Organization. This resulted in the incorporation of broadband targets into the Millennium Development Goals and the creation of the Broadband Commission, a joint undertaking of both agencies. In Southeast Asia, along with Cambodia and the Lao People's Democratic Republic (Lao PDR), Myanmar has yet to adopt a national broadband plan (Table A.1). ${ }^{2}$

\section{LEGAL AND REGULATORY FRAMEWORK}

The government has begun updating its laws governing the telecommunications sector to include ICTrelated services. The main objective of the new Telecommunications Law, passed in October 2013, is to liberalize the market to allow for more private domestic and foreign operators and investors to provide efficient ICT services. The law's provisions expand the telecommunication network throughout the country and facilitate the sector's development (ITU 2012a). It provides for the establishment of the types of licenses, and the basic rules on interconnection, competition, and dispute resolution. The law sets out the authority and powers of the MCIT and, more importantly, it provides for the creation of an independent regulator, the Myanmar Telecommunications Commission by 2015 and the government's overall policy on private sector participation in the sector. It also contains modern ICT elements, including a requirement for access and interconnection (and infrastructure sharing), competition safeguards, and a licensing structure similar to other ASEAN markets. The law was developed following a year of wide-ranging consultations with stakeholders.

Under the new Telecommunications Law, the MCIT is mandated to establish mechanisms to fulfill universal service obligations, including establishing a universal service fund. Notifications and special orders are being promulgated to allow private domestic companies to provide telecommunications services (Smith 2012). In addition, the law also provides for transition

\footnotetext{
However, ITU selected Myanmar as one of the four countries in Asia and the Pacific (Nepal, Samoa, and Viet Nam were the others) where the ITU itself developed a national pilot wireless broadband master plan for the country. The master plan is titled Wireless Broadband Masterplan for the Union of Myanmar of ITU. The Government of Myanmar also has broad action items related to broadband deployment under the National Broadband Deployment Plan (http://www.itu.int/ITU-D/asp/CMS/Events/2010/CLMV/S10-3_Salai_Samuel_Win_Tin.pdf).
} 
arrangements wherein the existing Post and Telecommunications Department (PTD) under the MCIT will be in charge of regulatory functions, such as numbering and spectrum planning. The PTD, with World Bank assistance, among other things, will develop an operational sector road map, institute a process of formulating and adopting regulations, and develop and promulgate subsidiary legislations to complement the new Telecommunications Law and help the ICT industry move forward (ITU 2012a). These include regulations on licensing, competition, access, and spectrum and numbering that will enable the MCIT to address bottlenecks to fair competition and increased private participation in the sector.

It is envisioned over the next few years that Myanmar's ICT market structure will change from that of monopoly into a multioperator environment. Under this transformation, the PTD will transition into an independent telecommunications regulator, the Myanmar Telecommunications Commission. This will be established under a provision of the new Telecommunications Law. State-owned Myanma Posts and Telecommunications (MPT) will be restructured into a commercial entity and, eventually, privatized. The MCIT will be responsible for making ICT sector policy and will be the main line ministry supporting the implementation of e-government initiatives.

As for an overall ICT regulatory framework, Myanmar is still adopting the necessary regulations to implement the new Telecommunications Law. For example, it is revising the Electronic Transaction Law to reflect good practice, which is largely modeled on the UN Model Law on Electronic Commerce (1996, as amended) and the UN Model Law on Electronic Signatures (2001). Three laws and regulations govern ICT development:

(i) The Computer Science Development Law of 1986 defines and provides measures for the development and dissemination of computer science and technology, including the supervision of imports and exports of computer software and information.

(ii) The Wide Area Network Order of 2002 allows for the establishment of a computer web using a wide area network; it focuses on prohibiting illegal acts relating to network usage.

(iii) The Electronic Transactions Law of 2004 aims to build trust in e-commerce, egovernment, and online banking. But moves are under way to replace this law, because it only covers a small part of a comprehensive informatization promotion plan (Orbicom and International Development Research Centre 2009), and it includes provisions that can infringe on citizens' rights and privileges in relation to the free flow of information and free speech.

Myanmar still has no law or regulations on intellectual property rights, privacy, right to information, or legislation related to cybercrimes. While these are definitely issues government has been made aware of, no definite plan or target has been set on when these will be drafted and the timing of its approval and implementation.

Other laws also have bearing or indirectly affect the development of the ICT sector (ITU 2012a). These include the:

(i) The State-owned Economic Enterprises Law of 1989 grants government the sole right to carry out a range of economic enterprises as state-owned economic enterprises, including a postal and telecommunications service. But in accordance with Section 4 of the law, the state-owned enterprise acting on the country's interest is permitted to enter into joint ventures with any other person or economic entity, subject to conditions. 
(ii) The Myanmar Special Economic Zone Law of 2011, which provides for the establishment of special economic zones, including information and telecommunication technology zones (ITU 2012a).

(iii) The Foreign Investment Law of 2013 allows for 100\% foreign ownership of local businesses with approval from the Foreign Investment Commission in many areas of investments, including ICT (Deloitte Southeast Asia 2012).

In the regulatory environment, Myanmar is the only country in Southeast Asia without a separate telecom or ICT regulator, one of the main building blocks of regulatory reform worldwide (Table A.2) (Ramamurthy 2013). Although the PTD is tasked as the telecoms and ICT "regulator," it is not an autonomous entity compared to regulators in other Southeast Asian countries, notably those in Malaysia, the Philippines, Singapore, and Thailand. Moreover, there is a perception of insufficient transparency and public participation in the policies and laws that concern the citizenry in as much as public consultations are not mandatory before regulatory decisions are conducted.

Given the nascent nature of the information technology (IT) industry, regulatory enforcement has been primarily focused on ex ante regulation (for example, licensing, assigning spectrum and other scarce resources, and dealing with interconnection issues) and general competitive issues (for example, mergers and acquisitions, and dominance and significant market power in converged technologies and services). Ex post regulations such as imposing remedies, sanctions, and penalties for market abuse by operators with significant market power, handling consumer complaints, and other issues such as copyright, privacy, cybercrime, and online content have yet to be established. The current processes in enforcement and dispute resolution are regarded as unfavorable to consumers and the general public because these do not benefit from public consultations. Regulatory decisions are made unilaterally and do not permit consumer complaints, contrary to usual practice in other countries (Table A.7).

The dispersed assignments of regulatory functions to various ministries, departments, and committees in Myanmar are in stark contrast to the tight regulatory environment existing today in most countries in Southeast Asia. In Myanmar, critical functions, which are usually assigned to the regulator, are scattered across different institutions. While the PTD is the supposed regulator, licensing, price regulation, radio frequency allocation and assignment, and spectrum monitoring and enforcement are under the MCIT. Some other regulatory functions including numbering, service quality monitoring, broadcasting (radio and TV transmission), and IT are shared by the MCIT with operators and other ministries. However, the following areas remain unregulated: interconnection rates, technical standards setting, type approval, universal service and access, quality of service standards setting, enforcement of service obligations, broadcasting content, and internet content.

\section{REGULATORY POLICY BY SPECIFIC AREA}

\section{A. Competitive Markets}

As a monopoly, MPT is the sole provider of mobile and fixed telephony services. Currently, 14,000 kilometers of fiber optics and around 1,800 towers connect Myanmar, 80\% of this infrastructure is owned by the military, with the MPT owning the rest (Deloitte Southeast Asia 2012). Even though a monopoly, MPT has the option to grant distribution rights to trusted companies, and smaller firms seeking vending rights must purchase equipment from these distributors (Freedom House 2012 and 2013). Internet services, which were only introduced in Myanmar in 1999, are provided by just a few 
providers: MPT, public company Yatanarpon Teleport, and privately owned Red Link Communications, SkyNet, and other Fiber To The Home providers. ICT services are still mainly under the control of the government. Although foreign companies such as Huawei and ZTE are now selling telecommunications-related equipment such as handsets and satellite equipment (Nomura Equity Research 2012), no competition-related policy or regulation on handset distribution is in force.

Myanmar is the only country in Southeast Asia with a monopolistic structure in most of its ICT services (Table 1). In this regard, the new Telecommunications Law intends to address competition and price setting issues. At present, tariff setting and approval is under the jurisdiction of the PTD. The law provides that "a licensee shall submit the schedules of tariffs for the existing services or the services to be introduced in respect of any telecommunications service business to the regulator; the regulator shall allow the proposed schedules of tariffs with the approval of the Ministry" (Vanderbruggen and Naing 2012).

Table 1: Level of Competition in Southeast Asia's ICT Sector, 2014

\begin{tabular}{|c|c|c|c|c|c|c|c|c|c|c|}
\hline & $\mathrm{BRU}$ & CAM & INO & $\mathrm{LAO}$ & MAL & MYA & $\mathrm{PHI}$ & SIN & THA & VIE \\
\hline Cable television & $N$ & $N$ & C & $\ldots$ & $\mathrm{N}$ & $M$ & C & $\mathrm{N}$ & $\begin{array}{c}C \\
(2012)\end{array}$ & C \\
\hline $\begin{array}{l}\text { Domestic fixed } \\
\text { long distance }\end{array}$ & M & C & $\mathrm{P}$ & P & $\begin{array}{c}C \\
(1998)\end{array}$ & $M$ & C & $\begin{array}{c}C \\
(2000)\end{array}$ & $\begin{array}{c}C \\
(2005)\end{array}$ & C \\
\hline Leased lines & $P$ & C & C & $\ldots$ & $\begin{array}{c}C \\
(1998)\end{array}$ & $M$ & C & $\begin{array}{c}C \\
(2000)\end{array}$ & C & C \\
\hline $\begin{array}{l}\text { Local fixed line } \\
\text { services }\end{array}$ & M & C & P & $\mathrm{P}$ & $\begin{array}{c}C \\
(1998)\end{array}$ & $M$ & C & $\begin{array}{c}C \\
(2000)\end{array}$ & C & C \\
\hline Mobile & $\mathrm{P}$ & C & C & $\mathrm{P}$ & $\begin{array}{c}C \\
(1998)\end{array}$ & $M$ & C & $\begin{array}{c}C \\
(2000)\end{array}$ & $P$ & C \\
\hline $\begin{array}{l}\text { Very small } \\
\text { aperture terminal } \\
\text { (VSAT) }\end{array}$ & P & C & C & $\ldots$ & $\begin{array}{c}C \\
(1998)\end{array}$ & $M$ & C & $\begin{array}{c}C \\
(2000)\end{array}$ & P & C \\
\hline
\end{tabular}

... = not applicable, $\mathrm{BRU}=$ Brunei Darussalam, $\mathrm{C}=$ full competition, $\mathrm{CAM}=$ Cambodia, $\mathrm{ICT}=$ information and communication technology, INO = Indonesia, $\mathrm{LAO}=$ Lao People's Democratic Republic, $\mathrm{M}=$ monopoly, $\mathrm{MAL}=$ Malaysia, $\mathrm{MYA}=$ Myanmar, $\mathrm{N}=$ not available, $\mathrm{P}=$ partial competition, $\mathrm{PHI}=$ Philippines, $\mathrm{SIN}=$ Singapore, $\mathrm{THA}=$ Thailand, $\mathrm{VIE}=\mathrm{Viet} \mathrm{Nam}$.

Source: International Telecommunication Union, World Telecommunication/ICT Regulatory Database. http://www.itu.int/net4/itu-d/icteye/ AdvancedDataSearch.aspx (accessed September 2015).

\section{B. Ownership}

There are two ways of bringing new players into the ICT sector: privatization of incumbent stateowned enterprises and opening up the sector to foreign investment. The latter became a recent policy priority after Myanmar allowed 100\% foreign ownership of a company in 2010. This policy is more liberal than foreign ownership levels in Malaysia (30\% in 2010) and the Philippines (40\% in 2010) (Table 2).

Even though restrictions to foreign participation and ownership have been relaxed, foreign investment remains limited due to political uncertainties, macroeconomic instability, and weak institutions. This may change, as the new Foreign Investment Law could set the stage for developing regulatory and operational guidelines for foreign investors.

Specifically for telecommunications, the government aims to fully liberalize a market that has been state-owned for the last 6 decades. The new Telecommunications Law allows foreign investors to hold a license subject to government approval and certain conditions. The law's provisions cover the number of operator licenses, spectrum allocation guidelines, universal service obligations, regulatory 
framework, interconnections, and network sharing. In January 2013, Myanmar called expressions of interest on tenders for two telecommunication service licenses from foreign investors. The highly contested licenses were awarded to Norway's Telenor ASA and Qatar Telecom QSC in June 2013; these companies are Myanmar's first foreign telecommunications operators.

Table 2: Foreign Ownership in ICT Sector in Southeast Asia (\% allowed)

\begin{tabular}{lrr}
\hline & 2005 & 2010 \\
\hline Brunei Darussalam & 49 & 49 \\
Cambodia & $49-100$ & 100 \\
Indonesia & $\ldots$ & 35 \\
Lao PDR & $49-100$ & $49-100$ \\
Malaysia & 30 & 30 \\
Myanmar & 0 & 100 \\
Philippines & 40 & 40 \\
Singapore & 100 & 100 \\
Thailand & 20 & 49 \\
Viet Nam & $\ldots$ & $\ldots$ \\
\hline
\end{tabular}

... = data not available, ICT = information and communication technology, Lao PDR = Lao

People's Democratic Republic.

Source: World Bank and International Telecommunication Union 2012.

\section{Licensing}

The licensing of operators and setting license conditions is a fundamental component of sector regulation. PTD has de facto responsibility for the issuance of licenses. ${ }^{3}$ Currently, however, no formal licensing regulations are in force under the old legislation. Licensing-related regulations are stated in several chapters of the new Telecommunications Law: (i) Chapter IV on licensing, which describes the four service types (network facility service, network service, content application service, and application service) covered by license; (ii) Chapter $V$ on telecommunication equipment licenses, which determine the terms and conditions for an equipment license; and (iii) Chapter VI on general license conditions, which details the conditions set out by the MCIT and the radio spectrum plan that licensees must abide by. The different licenses have a minimum duration of 5 years and a maximum duration of 20 years (Vanderbruggen and Naing 2012).

\section{Spectrum Management}

The growth of broadband services over wireless networks is putting pressure on existing resources such as radio spectrum. ${ }^{4}$ Many countries have started assigning spectrum through competitive mechanisms such as spectrum auctions, to maximize available resources and the potential benefits to

3 Licenses regulated by PTD are the (i) wide area network license (establishment and service), (ii) service license, (iii) station license, (iv) satellite phone and very small aperture terminal license, (v) mobile license, (vi) microwave license, (vii) wireless local loop license, (viii) long-range and short-range cordless phone license, (ix) point-to-point license, (x) telecom equipment repair license, (xi) telecom equipment dealer license, (xii) certificating authority license, and (xiii) public access center license.

4 Radio spectrum typically refers to the full frequency range from 3 kilohertz to 300 gigahertz that may be used for wireless communication, such as mobile telephones and broadband services. From an economic point of view, radio spectrum is a national resource, such as water, land, gas, and minerals, but reusable. A balance between overexploitation and underexploitation is needed in the management of the spectrum, and this requires regulation at national, regional, and global levels. 
consumers. ${ }^{5}$ Although new market-based mechanisms such as in-band migration, spectrum sharing, and spectrum trading are being introduced in developed countries, Myanmar, like most countries in the ASEAN region, still retains centralized control over its spectrum resources. Since there are only few operators of telecommunication services in Myanmar, the demand for spectrum is significantly lower and, as a result, few problems over its use.

With no transparent and consistent spectrum policy in place, there is no mechanism to protect assigned frequencies as well as monitoring of these (ITU 2012a). Service providers are operating but their operating licenses have yet to be issued. ${ }^{6}$ Market-based mechanisms such as secondary trading and band migration are also nonexistent, unlike in other Southeast Asian countries (Table A.4). There is a brief provision for spectrum management in the new Telecommunications Law, which states: "the Ministry (of Communications and Information Technology) is assigned to manage the frequency spectrum under the international telecommunications conventions, while the independent regulator assigns the frequency bands under the national frequency allocation plan."

\section{E. Infrastructure Sharing and Interconnection}

Given that entry of foreign operators in the market was only permitted recently, competition has yet to emerge and no operator has significant market power. ${ }^{7}$ Infrastructure sharing lowers the cost of deploying infrastructure to achieve widespread and affordable access to ICT by making competitors act as partners. In Southeast Asia, the emerging trend is to permit infrastructure sharing for mobile operators, such as towers, base stations, and posts (Table A.3). The new Telecommunications Law has a brief provision on sharing network facilities equipment. It also encourages infrastructure sharing, but detailed guidelines for this need to be developed.

To introduce competition in telecommunications markets, regulators impose interconnection requirements on dominant carriers. ${ }^{8}$ The new Telecommunications Law prescribes only minimal guidance on interconnection-related policy and issues, stipulating that the PTD will set out interconnection rules. ${ }^{9}$ Thus, the PTD is the agency responsible for developing regulations governing interconnection. The current practice is that interconnection agreements must be lodged with the PTD to become legally enforceable. The agreements provide that interconnection must be on an "equitable and nondiscriminatory basis" and "shall not be of lower technical standard and quality than the technical standard or quality provided in the licensee's own network facilities or network services." It is unclear, however, whether interconnection fees will be freely set between parties or, as seems more likely, determined by the regulator (Vanderbruggen and Naing 2012).

5 Under a spectrum auction, a government uses an auction system to sell the rights (licenses) to transmit signals over specific bands of the electromagnetic spectrum and to assign scarce spectrum resources.

6 Many technologies are available for wireless data communications, such as $3 G$ (International Mobile Telecommunications [IMT]), WiMax (Worldwide Interoperability for Microwave Access), and LTE (Long Term Evolution). $3 \mathrm{G}$ is the third generation of mobile telecommunications technology; its network support services provide an information transfer rate of at least 200 kilobits per second. WiMAX and LTE are faster and more cost-efficient compared to $3 \mathrm{G}$ and can be considered fourth generation technologies. Both WiMAX and LTE are expected to provide up to 1 gigabit per second.

7 This is prior to the awarding of licenses to foreign investors last June 2013 and it will take a while to determine the outcome.

8 In telecommunication, interconnection is the physical linking of a carrier's network with equipment or facilities not belonging to that network. The term may refer to a connection between a carrier's facilities and the equipment belonging to its customer, or to a connection between two or more carriers.

9 The draft law is also silent on number portability which, similar with interconnection, lowers the barrier for consumers to switch service providers. This process allows subscribers to maintain their assigned mobile numbers when switching mobile phone providers. 


\section{F. Voice over Internet Protocol}

The government has used internet surveillance and censorship to monitor activities, especially of civilians. Myanmar has the most restricted environment possible for voice over internet protocol (VolP), as individual users are not allowed to make VolP or internet telephony phone calls. VolP services had earlier faced significant resistance from the government. ${ }^{10}$

There is no established policy or regulation specifically for VolP. This is in contrast with a liberalized environment in which users may freely use the technology (Table A.5). The ban on VolP technologies imposed in 2008, in particular on Skype, was lifted in 2012. While the government has relaxed the use of VolP, it retains control over the country's international connection to the internet. In 2010, the authorities restructured the internet service provider (ISP) system, where existing ISPssuch as Yatanarpon Teleport, which mainly serves civilian users and a newly established Naypyitaw ISP, which serves most government ministries-are connected to the international internet via MPT.

\section{G. Universal Access and Service}

The common objective of a universal policy as defined by ITU is to provide or maintain ICT services to those who would not normally be served, such as people living in rural areas (high cost service areas), lower income people, people with physical disabilities, and so on. This policy refers to both universal service and universal access. The former aims to promote universal availability of connections by individual households to public telecommunications networks; for example, mobile phones and personal digital assistants." Universal access aims to provide every person with reasonable access to a publicly available telecommunication center (for example, payphones and community phone shops), which is considered a first step to achieving universal service.

The Government of Myanmar, under the new Telecommunications Law, is mandated through the independent regulator to formulate plans to expand telecommunications infrastructure and enhance service in underserved areas. The law also provides for the MCIT to set up a universal service fund for all universal telecommunication service activities. Earlier, achieving universal service and access meant providing only fixed lines for a private residential service among various voice-related services and telecenters. But with the new law, Myanmar has the opportunity to adopt a more comprehensive definition of universal access and service following those of Brunei Darussalam, Thailand, and Malaysia in the areas of fixed lines for public payphones, individual mobile cellular service, and public mobile payphones, provisions for VolP services, telecenters, schools, and services for the impaired and elderly (Table A.6). ${ }^{12}$

10 VolP is a methodology and a group of technologies for the delivery of voice communications and multimedia sessions over internet protocol (IP) networks, such as the internet. Other terms commonly associated with VolP are IP telephony, internet telephony, voice over broadband, broadband telephony, IP communications, and broadband phone service.

1 Universal service is a practical ICT policy objective for developed countries, but it is not economically feasible for developing countries.

$12 \mathrm{MCIT}$ recently invited eligible consulting firms to indicate interests (with deadline set for 24 August 2015) to design Myanmar's universal service strategy and provide for its implementation in a number of pilot areas to accelerate the development of rural telecommunications infrastructure and services in locations that are unlikely to attract private investment. 


\section{INSTITUTIONAL FRAMEWORK}

The MCIT, formerly the Ministry of Communications, Posts and Telegraphs, is the overseeing ministry for ICT development. Chaired by a minister, its overall responsibilities include (i) issuing ICT regulations and licenses; (ii) monitoring ICT services in accordance to existing laws, rules, and regulations; (iii) implementing a reliable and trustworthy ICT service; (iv) developing and establishing a secure infrastructure and private network of government agencies; ( $v$ ) implementing and controlling an e-government gateway and data center; and (vi) providing ICT-related training and transfer technology. The MCIT is also mandated to implement ICT-related development plans, with Myanma Posts and Telecommunications (MPT) and the PTD being the two implementing agencies under the ministry (Figure 1).

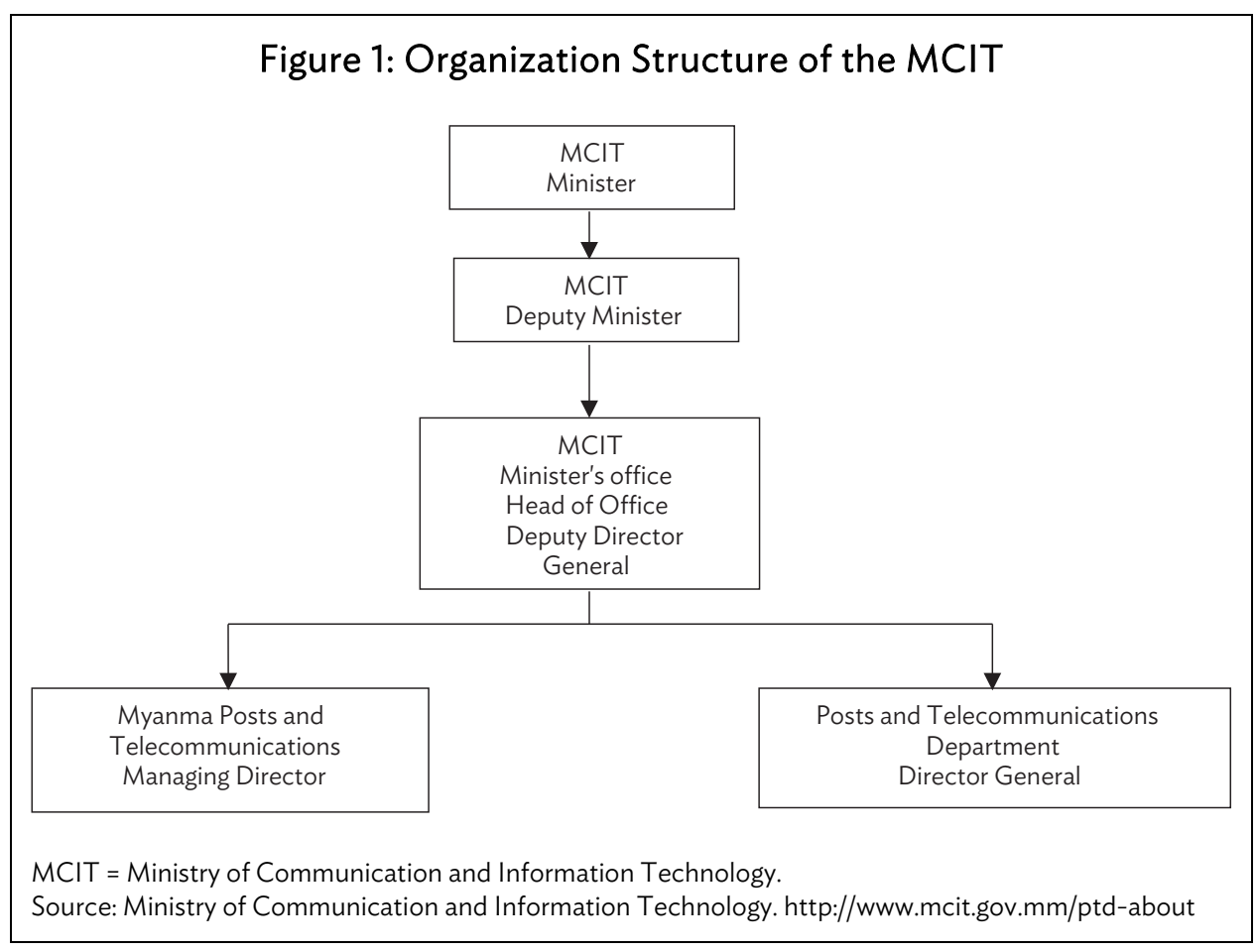

Under the present setup, PTD serves as the telecommunications and ICT regulator and supports MCIT on its policy-making functions and provides regulatory and legal support to the ministry. Headed by a director general, its main duties and responsibilities include (i) supervision of the operation of telecommunications and postal services; (ii) supervision of certification authorities; (iii) management of radio frequency spectrum; (iv) coordination and cooperation with international organizations; (v) issuance and regulation of different licenses; (vi) issuance and regulation of different telecommunications-related certificates; (vii) review of available modern technologies and providing advice on them to concerned authorities; and (viii) supervision of production, import, export, sale, and use of telecommunications equipment within the country (MCIT website). It is also tasked to regularly update and revise existing rules and regulations on telecommunications and ICT to respond to a constantly changing technological environment, and international and regional developments.

MPT is the main operator that provides all telecommunications services, including fixed and mobile access, local, national and international calls, and leased lines. Its main roles and responsibilities include establishing the infrastructure for information and communication services and the 
deployment, maintenance, extension, and renovation of ICT networks, communication centers, and routes.

Aside from MCIT, a number of bodies and councils are tasked with ICT development and management. Myanmar Computer Science Development Council is a statutory body with constitutional powers and responsibilities; these include formulating policies for the growth of the ICT sector and promoting the use of ICT (ESCAP 2004). Two main bodies fall under the council: the eNational Task Force and the Myanmar Computer Federation. The e-National Task Force was created in 2000 to bridge the digital divide and accelerate the development of ICT to the level of more developed ASEAN countries. The Myanmar Computer Federation's main responsibility is the development of computer technology in the private sector, though it also provides recommendations for the ICT master plan.

The federation oversees three industry associations: (i) Myanmar Computer Professionals Association, which aims to upgrade knowledge in computer science and ICT; (ii) Myanmar Computer Industry Association, a group of enterprises engaged in computer production, hardware and software supply, and services and software production; and (iii) Myanmar Computer Enthusiasts Association, a group of nonprofessional ICT practitioners. These organizations were formed to mobilize all computer technicians and entrepreneurs in the country (UN Statistical Institute for Asia and the Pacific 2007). Despite the fairly large number of organizations under the Myanmar Computer Science Development Council, its involvement and contribution to the development of the ICT sector has been minimal (Freedom House 2012).

\section{CURRENT STATE OF INFORMATION AND COMMUNICATION TECHNOLOGY}

Although a variety of technologies have been adopted to support the ICT sector, the infrastructure remains underdeveloped. Table 3 presents a technical summary of Myanmar's ICT infrastructure. While the country is trying to catch up with advanced technology, progress is slow, with only Yangon and the Yangon-Mandalay route using underground optical fiber cables. And reliable international connection was only made possible with the completion of a telecommunications hub in Yatanarpon Cyber City in late 2007.

MPT operates the global system for mobiles (GSM) and code division multiple access (CDMA) mobile communication networks. CDMA450 coverage includes the Bengal Bay and Andaman Sea regions, and major cities in states and divisions, and provides service wider than GSM coverage. In addition, the CDMA800 service is provided by about 30 stations, mainly in Yangon and Mandalay (Ministry of Communications, Posts, and Telegraphs, Korea International Cooperation Agency, and Electric and Telecommunications Research Institute 2011).

\section{A. Accessibility}

The penetration or access rates of various ICT services in Myanmar are incredibly low. Growth has been stagnant, except in mobile cellular penetration, despite a growing population and an increasing need for the country to be interconnected domestically and internationally (Table 4). 
Table 3: Technical Summary of Myanmar ICT Infrastructure

\begin{tabular}{|c|c|c|c|}
\hline Indicator & Statistics & Indicator & Statistics \\
\hline Total telephone lines & $\begin{array}{l}2,871,265 \\
\text { Fixed lines (including wireless } \\
\text { local loop): } 866,084 \\
\text { Mobile lines: } 2,276,000\end{array}$ & International gateways & $\begin{array}{l}2 \text { (NGN-IP-IGW/DMS- } \\
300 \text { with IP Trunk } 500 \\
\text { E1) }\end{array}$ \\
\hline National backbone & Fiber between major cities & International channels & 4,627 \\
\hline Cross-border fiber & $\begin{array}{l}\text { India-Myanmar } \\
\text { PRC-Myanmar } \\
\text { Thailand-Myanmar } \\
\text { Lao PDR-Myanmar }\end{array}$ & Internet gateway & 1 \\
\hline International links & Cable/satellite & PSTN Exchanges & 913 \\
\hline Last-mile links & $\begin{array}{l}\text { Dedicated wireless broadband } \\
\text { access } \\
\text { MPT satellite broadband }\end{array}$ & Mobile exchanges & 14 \\
\hline Internet hosts & 25,690 & Transit exchanges & 11 \\
\hline $\begin{array}{l}\text { Internet backbone } \\
\text { bandwidth }\end{array}$ & 4.385 Gigabits per second & Microwave stations & 340 \\
\hline Internet subscribers & $\begin{array}{l}52,071 \\
\text { FTTH users (6500) }\end{array}$ & $\begin{array}{l}\text { Satellite } \\
\text { terminals/stations }\end{array}$ & $\begin{array}{l}\text { 2,065 (MPT satellite } \\
\text { terminals)/1 (Intelsat Es) } \\
+11 \text { (VSAT stations) }\end{array}$ \\
\hline Public access centers & $2,500+$ & & \\
\hline
\end{tabular}

FTTH = fiber to the home, ICT = information and communication technology, Lao PDR = Lao People's Democratic Republic, MPT = Myanma Posts and Telecommunications, PRC = People's Republic of China, PSTN = public switched telephone network, VSAT = very small aperture terminal.

Source: International Telecommunication Union 2012a.

Table 4: Penetration and Usage Rates of ICT Services

\begin{tabular}{|c|c|c|c|c|c|c|c|c|c|c|c|}
\hline & & BRU & CAM & INO & LAO & MAL & MYA & $\mathrm{PHI}$ & SIN & THA & VIE \\
\hline \multirow{5}{*}{$\begin{array}{l}\text { Fixed } \\
\text { telephone (per } \\
100 \text { people) }\end{array}$} & 1990 & 13.62 & 0.03 & 0.60 & 0.16 & 8.71 & 0.17 & 0.98 & 34.94 & 2.34 & 0.14 \\
\hline & 2000 & 24.62 & 0.25 & 3.19 & 0.76 & 19.76 & 0.56 & 3.94 & 49.67 & 8.97 & 3.14 \\
\hline & 2010 & 19.95 & 2.50 & 17.01 & 1.61 & 16.30 & 0.95 & 3.57 & 39.30 & 10.29 & 16.14 \\
\hline & 2012 & 17.21 & 3.93 & 15.39 & 6.77 & 15.69 & 0.99 & 3.61 & 37.48 & 9.55 & 10.52 \\
\hline & 2014 & 11.40 & 2.84 & 11.72 & 13.36 & 14.61 & 0.98 & 3.09 & 35.52 & 8.46 & 6.01 \\
\hline \multirow{5}{*}{$\begin{array}{l}\text { Mobile cellular } \\
\text { (per } 100 \\
\text { people) }\end{array}$} & 1990 & 0.69 & 0.00 & 0.01 & 0.00 & 0.48 & 0.00 & 0.00 & 1.71 & 0.11 & 0.00 \\
\hline & 2000 & 28.63 & 1.07 & 1.76 & 0.24 & 21.87 & 0.03 & 8.31 & 70.12 & 4.90 & 0.97 \\
\hline & 2010 & 108.62 & 56.74 & 87.79 & 62.59 & 119.74 & 1.14 & 88.98 & 145.40 & 108.02 & 125.29 \\
\hline & 2012 & 113.95 & 128.53 & 114.22 & 64.70 & 141.33 & 7.06 & 105.45 & 152.13 & 127.29 & 145.02 \\
\hline & 2014 & 110.06 & 155.11 & 126.18 & 66.99 & 148.83 & 49.47 & 111.22 & 158.13 & 144.44 & 147.11 \\
\hline \multirow{5}{*}{$\begin{array}{l}\text { Households } \\
\text { with a } \\
\text { computer (\%) }\end{array}$} & 2005 & 55.00 & 1.80 & 3.67 & 2.00 & 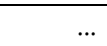 & 0.27 & 6.60 & 74.00 & 15.50 & 6.30 \\
\hline & 2010 & 79.57 & 4.33 & 10.8 & 6.86 & 61.80 & 1.33 & 13.10 & 84.00 & 22.84 & 14.21 \\
\hline & 2012 & 86.92 & 6.30 & 14.86 & 8.68 & 66.90 & 2.26 & 16.94 & 85.00 & 26.91 & 17.48 \\
\hline & 2014 & 90.6 & 9.25 & 17.8 & 9.60 & 65.10 & 2.8 & 18.7 & 87.00 & 33.90 & 19.00 \\
\hline & & (2013) & (2013) & & (2013) & (2013) & (2013) & (2013) & (2013) & & (2013) \\
\hline \multirow{5}{*}{$\begin{array}{l}\text { Households } \\
\text { with internet } \\
\text { access at home } \\
\text { (\%) }\end{array}$} & 2005 & 50.00 & 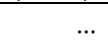 & 1.00 & 1.00 & 15.00 & 0.19 & 4.30 & 66.00 & 7.18 & 1.50 \\
\hline & 2010 & 65.00 & 1.60 & 4.58 & 3.37 & 55.6 & 1.01 & 10.10 & 82.00 & 11.42 & 12.50 \\
\hline & 2012 & 72.44 & 3.94 & 6.45 & 5.07 & 64.7 & 1.79 & 18.9 & 87.70 & 17.55 & 15.60 \\
\hline & 2014 & 75.80 & 5.53 & 29.1 & 5.10 & 64.7 & 2.20 & 22.9 & 87.20 & 33.80 & 17.10 \\
\hline & 2000 & (2013) & (2013) & 0.00 & (2013) & (2013) & (2013) & (2013) & $\begin{array}{r}(2013) \\
1.76\end{array}$ & $\ldots$ & $(2013)$ \\
\hline \multirow{4}{*}{$\begin{array}{l}\text { Fixed } \\
\text { broadband } \\
\text { internet (per } \\
100 \text { people) }\end{array}$} & 2005 & 2.21 & 0.01 & 0.05 & 0.01 & 1.87 & 0.00 & 0.14 & 14.60 & 0.85 & 0.25 \\
\hline & 2010 & 5.42 & 0.25 & 0.95 & 0.09 & 7.42 & 0.04 & 1.84 & 26.35 & 4.90 & 4.12 \\
\hline & 2012 & 4.81 & 0.20 & 1.21 & 0.11 & 9.99 & 0.12 & 14.09 & 27.02 & 6.77 & 5.26 \\
\hline & 2014 & 7.15 & 0.21 & 1.19 & 0.16 & 10.14 & 0.27 & 23.22 & 27.79 & 8.21 & 6.48 \\
\hline
\end{tabular}


Table 4 continued

\begin{tabular}{|c|c|c|c|c|c|c|c|c|c|c|c|}
\hline & & BRU & CAM & INO & LAO & MAL & MYA & $\mathrm{PHI}$ & SIN & THA & VIE \\
\hline & 2000 & 9.00 & 0.05 & 0.93 & 0.11 & 21.38 & & 1.98 & 36.00 & 3.69 & 0.25 \\
\hline Individuals & 2010 & 53.00 & 1.26 & 10.92 & 7.00 & 56.30 & 0.25 & 25.00 & 71.00 & 22.40 & 30.65 \\
\hline using the & 2012 & 60.27 & 4.94 & 14.7 & 10.75 & 65.80 & 1.07 & 36.24 & 72.00 & 26.46 & 39.49 \\
\hline internet (\%) & 2014 & $\begin{array}{r}64.50 \\
(2013)\end{array}$ & $\begin{array}{r}6 \\
(2013)\end{array}$ & 17.10 & $\begin{array}{r}12.50 \\
(2013)\end{array}$ & $\begin{array}{r}66.97 \\
(2013)\end{array}$ & $\begin{array}{r}1.20 \\
(2013)\end{array}$ & $\begin{array}{r}37 \\
(2013)\end{array}$ & $\begin{array}{r}73.00 \\
(2013)\end{array}$ & $\begin{array}{r}28.94 \\
(2013)\end{array}$ & $\begin{array}{r}43.9 \\
(2013)\end{array}$ \\
\hline
\end{tabular}

$\ldots=$ data not available, $\mathrm{BRU}=$ Brunei Darussalam, $\mathrm{CAM}=\mathrm{Cambodia}, \mathrm{INO}=$ Indonesia, $\mathrm{ICT}=$ information and communication technology, $\mathrm{LAO}=$ Lao People's Democratic Republic, MAL = Malaysia, MYA = Myanmar, PHI = Philippines, SIN = Singapore, THA = Thailand, VIE = Viet Nam Sources: International Telecommunications Union, ICT Statistics. http://www.itu.int/en/ITU-D/Statistics/Pages/stat/default.aspx (accessed September 2015); International Telecommunications Union, World Telecommunication/ICT Indicators Database 2014. CD-ROM.

\section{Fixed Telephone and Mobile Cellular Services}

Myanmar has the lowest teledensity rate in Southeast Asia, with only 0.98 telephone lines per 100 people in 2014. This is up from 1982's extremely low level of 0.1, but Myanmar lags far behind its neighbors. Viet Nam achieved a teledensity rate of 6.01 in 2014 while coming from a similarly low level in 1990.

Myanmar's penetration rate for mobile cellular services is rising steadily, increasing from 1.14 subscriptions per 100 people in 2010 to 49.47 subscriptions per 100 people in 2014. Even so, it still has one of the lowest penetration rates compared with the 2014 average in Asia and the Pacific (11.9 in fixed telephone and 90.6 in mobile), and other developing countries globally ( 9.4 in fixed telephone and 91.8 in mobile)

Telecommunications infrastructure has always favored urban areas, meaning Mandalay and Yangon have higher penetration rates, ranging between 4\% and 6\% (Paul Budde Communication 2010). But even this is low by regional standards and may be attributable to the monopolistic structure of Myanmar's fixed and mobile lines industry. As in Cambodia and Viet Nam, the main fixed line operator in Myanmar, MPT, is 100\% government-owned (and unlike Malaysia and Singapore). Since market competition has yet to happen, the unbundled access to the local loop, which is prevalent in competitive markets for fixed lines, is not required in Myanmar. ${ }^{13}$ This is unlike most countries in the region, where raw copper is used for full unbundling, line sharing for partial unbundling (that is, access only to the high-frequency portion of the local loop), and bit stream for wholesale access. New entrants in the market argue that without the local loop unbundling, they cannot enter the market effectively and supply various services. But this may soon change as the government has already started to allow the entry of domestic and foreign players (Deloitte Southeast Asia 2012).

\section{Computers and Internet Services}

At the household level, the accessibility of computers in Myanmar has improved by more than 10 times, from 0.27 households in 2005 to 2.8 households in 2013. However, the country ranks lowest in regional comparisons. The access rate was 9.25 in Cambodia and 9.6 in the Lao PDR in 2013. By regional comparison, it was 31.8 in Asia and the Pacific, and 29.2 in developing countries globally (in 2013).

13 Local loop unbundling is the regulatory process of allowing multiple telecommunications operators to use connections from the telephone exchange to the customer's premises. 
Although internet availability at the household level has improved by about 9 times, from 0.2 households in 2005 to 2.20 households in 2013, Myanmar still has the lowest penetration rates in Southeast Asia and is below the average of neighboring regions.

Broadband has recently been introduced in the country, though access is extremely limited with only 0.27 penetration rate in fixed wired broadband internet subscriptions. Again, this pales in comparison with access rates in Indonesia (1.19 in 2014) and the average of 8.48 in Southeast Asia

With the global trend of wireless technology, Myanmar's fixed wire penetration is not expected to increase dramatically. Future increases in internet penetration will therefore depend on the availability of affordable mobile internet, as evidenced by the success of WiMax in Yangon (Deloitte Southeast Asia 2012).

Internet service performance is better measured from its usage and service quality rather than simply the availability and accessibility of the infrastructure. The number of people using the internet in Myanmar has risen, although the uptake has been slow since its introduction in 1999 and was just $1.2 \%$ of population the in 2013. But, again, this rate is the lowest in Southeast Asia and even lower than other developing countries globally.

Speed and reliability is a measure of quality of internet service. International internet bandwidth, a key factor for providing high-speed internet access to a growing number of internet users, has grown exponentially in Southeast Asia (Table 5). Myanmar's low internet usage rates may be attributable to the quality of available internet bandwidth and connection. ${ }^{14}$ Although international bandwidth improved between 2003 and 2013, this was less dramatic compared with other countries in Southeast Asia. On a per-user basis, this has increased from 9 megabits per second (Mbit/s) in 2003, to $16,744 \mathrm{Mbit} / \mathrm{s}$ in 2013. Similarly, internet capacity, on a per user basis, improved 10 times, from 816 bits per second per internet user in 2003, to 8,180 bits per second per internet user in 2011. Although the country's internet's performance appears to be better than Brunei Darussalam, Cambodia, and the Lao PDR, its reliability has become an issue. From mid-October 2011 until January 2012, internet connection speeds slowed so dramatically that in provincial towns, it took 45 to 90 minutes to open a webpage. The very slow speed is mainly due to the internet infrastructure that is still limited to a single internet gateway to the global fiber optic network (Freedom House 2012).

Around 50\% of internet subscriptions in Myanmar had broadband access as of 2011, a big improvement from 3.8\% in 2005. ${ }^{15}$ In fact, broadband access is now comparable or even better than in Brunei Darussalam (20\%), Malaysia (30\%), and Viet Nam (31\%) (Table 5). But it is slightly lower than the average for Southeast Asia (52\%) and South Asia (52.9\%) in 2010 (World Bank and ITU 2012). Due to digital leapfrogging, Myanmar was able to take advantage of cheaper and faster broadband technology instead of using older and slower technologies such as internet dial-up.

14 International internet bandwidth is measured as the total used capacity of all internet exchanges (locations where internet traffic is exchanged) offering international bandwidth.

15 There are two main kinds of internet access: slower dial-up internet access, which uses the facilities of the public switched telephone network to establish a dialed connection to an ISP via telephone lines, and the faster broadband internet access. 
Table 5: Quality of Internet Service

\begin{tabular}{lrrrr}
\hline & \multicolumn{3}{c}{$\begin{array}{c}\text { Fixed Wired Broadband } \\
\end{array}$} & \multicolumn{2}{c}{$\begin{array}{c}\text { International Internet } \\
\text { Bandwidth }(\text { Mbit/s) }\end{array}$} & $\begin{array}{c}\text { Subscriptions (\% of total internet } \\
\text { subscription) }\end{array}$ \\
\hline & 2003 & 2013 & 2005 & 2011 \\
\cline { 2 - 5 } Brunei Darussalam & 182 & 13,000 & 45.2 & 20.0 \\
Cambodia & 18 & 8,446 & 11.7 & 86.7 \\
Indonesia & 1,059 & 400,000 & 5.8 & 57.5 \\
Lao PDR & 2 & 8,946 & 5.0 & 53.7 \\
Malaysia & 2,308 & 586,300 & 11.6 & 29.9 \\
Myanmar & 9 & 16,744 & 3.8 & 47.0 \\
Philippines & 2,323 & $2,097,148$ & 8.5 & 47.8 \\
Singapore & 15,564 & $2,294,400$ & 29.1 & 95.1 \\
Thailand & 1,438 & 724,708 & 70.3 & $\ldots$ \\
Viet Nam & 1,038 & 640,058 & 7.2 & 30.6 \\
\hline
\end{tabular}

$\ldots=$ not available, Lao PDR = Lao People's Democratic Republic, Mbit $/ \mathrm{s}=$ megabits per second.

Sources: International Telecommunication Union, World Telecommunication/ICT Indicators Database 2014. CD-

ROM; World Bank and International Telecommunication Union 2012.

The development of Myanmar's telecoms infrastructure and network systems had been slow due to the low foreign and domestic investment in the sector (Figure 2). The country invested one of the least amounts in telecommunication services in Southeast Asia in 2007, about $\$ 1$ million, compared with Indonesia's $\$ 3.7$ billion.

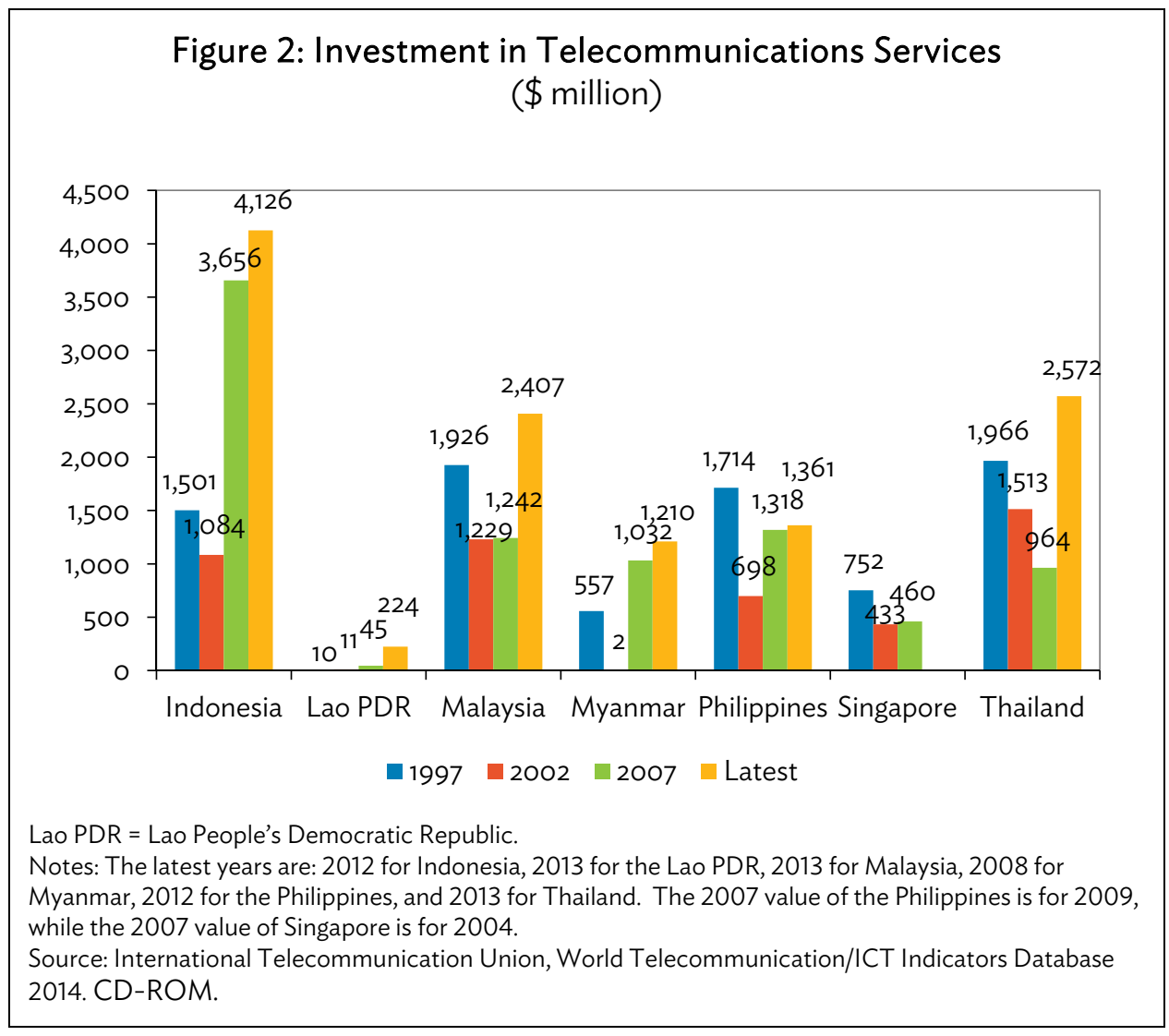


Poor domestic connectivity due to inadequate support infrastructure and an insufficient and unreliable supply of electricity constrain private investment that could expand Myanmar's ICT infrastructure. Because ICT is heavily reliant on electricity, it will be very difficult to expand existing ICT services. The poor accessibility to various divisions and areas of the country will also make it difficult to establish needed ICT infrastructure, such as communications and cell site towers, and underground cables.

Availability of ICT services in villages is limited. With few resources available, due to competing needs, telecommunications infrastructure development has favored urban areas, even though $75 \%$ to $80 \%$ of the population lives in rural areas. Rural areas are still on manual switching, while urban areas have upgraded to automatic switching systems. ${ }^{16}$ Growing private sector interest in the ICT sector has not benefited rural and remote areas, where penetration rates range from close to zero for internet to $2 \%$ for mobile cellular services (Table 6).

\section{Table 6: Percentage of Population with Access to ICT Services}

\begin{tabular}{lcccc}
\hline & Fixed Telephone & Mobile Cellular & Computer & Internet \\
\hline Total & 5.08 & 5.19 & 2.16 & 0.89 \\
Urban & 15.83 & 14.66 & 7.19 & 3.35 \\
Rural & 1.29 & 1.85 & 0.39 & 0.02 \\
\hline
\end{tabular}

$\mathrm{ICT}=$ information and communication technology.

Source: MNPED, Sida, UNICEF, and UNDP (2011).

\section{B. Affordability and Price Controls}

The cost of ICT services, with the exception of fixed telephone, is beyond the means of most of the population, with Myanmar's nominal gross domestic product per capita estimated at $\$ 834$ in 2012 and $\$ 1,203$ in 2014 (World Bank, World Development Indicators) (Table A.8).

Myanmar's fixed telephone rates, estimated at $\$ 0.9$ per month in 2010 , are the lowest in Southeast Asia, and much lower than regional averages- $\$ 6.9$ in Southeast Asia and $\$ 3.3$ in South Asia. By contrast, Myanmar's mobile cellular services, pegged at an average of $\$ 12.8$ per month in 2010, are the highest in Southeast Asia, except Brunei Darussalam. This is also higher than regional averages (\$8.9 in Southeast Asia and \$2.5 in South Asia) (World Bank and ITU 2012). However, there has been a noticeable downward trend in cost as mobile phones become cheaper and GSM phones emerge, which now include mobile internet access. Owning a mobile phone used to be beyond the means of most citizens, with the cost of a handset ranging from $\$ 600$ to $\$ 1,400$ and $\$ 150$ for a subscriber identity module (SIM) card (DBS Vickers Securities 2013). Moreover, MPT has been resisting the entry of private providers offering to sell mobile phone access at substantially lower rates (Rieffel 2012), at $\$ 200$ in 2012 (ESCAP 2013). In April 2013, however, SIM cards dropped to $\$ 2$ to increase the penetration rate (McKinsey Global Institute 2013).

A comparative analysis of the pricing of Myanmar's fixed broadband internet services showed mixed results. The rate of $\$ 28.5$ per month in 2010 favorably compares with other countries in Southeast Asia, where the average cost was \$38.6, and it was noticeably cheaper than in Brunei

16 Switching system (or public switched telephone network, as it is formally called) is the network of circuit-switched telephone networks, consisting of telephone lines, fiber optic cable, microwave transmission links, cellular networks, communications satellites, and undersea telephone cables; all interconnected by switching centers. This network allows any telephone to connect to another telephone in the world. 
Darussalam (\$50.5), Cambodia (\$47), and the Lao PDR (\$139.7) (World Bank and ITU 2012). But the rate was much more expensive than South Asia's average of $\$ 4.2$. The actual cost of broadband access in Myanmar is estimated at between $\$ 530$ and $\$ 588$, taking account of installation costs and other fees. In early 2013, however, MPT and Yatanarpon Teleport lowered installation costs to \$58 and $\$ 500$, respectively. The monthly fee for an asymmetric digital subscriber line service ranges from $\$ 30$ for a speed of 512 kilobits per second to $\$ 155$ for 3 Mbit/s (Freedom House 2013). The cost of an annual $1 \mathrm{Mbit} / \mathrm{s}$ broadband subscription, including installation, was about $132.8 \%$ of nominal gross domestic product per capita in 2012. It was the most unaffordable in Southeast Asia (ESCAP 2013).

The cost of an international call using internet telephony services in Myanmar is $\$ 0.41$ for payas-you-go per minute and $\$ 17.49$ for a monthly subscription, the most expensive rates in Southeast Asia. Because of economic barriers, mainly, most users rely on cybercafes, where access typically costs about MK200-MK400 (\$0.25-\$0.5) per hour in major cities and about MK500-MK600 in provincial towns (Freedom House 2012). The "prohibitive" cost is a result of retail price controls imposed in fixed, mobile, and broadband services except for international services. ${ }^{17}$ This is in stark contrast to the absence of price controls in Southeast Asia's liberalized ICT markets, such as Indonesia and Singapore. The lack of competition in internet services also constrains internet access for the general population, but this is expected to improve as more liberal regulations, especially for ICT, are formulated and implemented.

\section{BEYOND INFORMATION AND COMMUNICATION TECHNOLOGY INFRASTRUCTURE: HUMAN DEVELOPMENT, INDUSTRIES, E-GOVERNANCE}

The critical role of ICT has been recognized in catalyzing inclusive economic growth as well as in promoting human social development. ICT is both a sector in itself (ICT connectivity, infrastructure, and industries) and an enabler of transformation across sectors (World Bank 2011). Myanmar has clearly demonstrated its commitment to internet development with the establishment of Yatanarpon Cyber City, the government fiber network, and e-government projects, computer universities in regional areas, public access centers, and efforts at localization (ITU 2012a).

\section{A. Human Development}

ICT is knowledge-intensive and requires a certain level of literacy and numeracy for the appreciation and use of the service. In Myanmar, ICT skills are mainly provided by the 24 computer colleges and two universities with computer studies departments under the jurisdiction of the Ministry of Science and Technology. Other agencies, such as the Ministry of Education, which has its own programs for fostering highly skilled ICT graduates, and the private sector, which has built 90 computer schools, including 70 in Yangon, have also contributed to the increased number of ICT workers (Ministry of Communications, Posts and Telegraphs, Korea International Cooperation Agency, and Electric and Telecommunications Research Institute 2011). Informal certification programs, such as the Japanese Information Technology Engineer Examination, provide IT training opportunities to those who cannot afford or do not want to participate in formal education programs (Ministry of Communications, Posts and Telegraphs, Korea International Cooperation Agency, and Electric and Telecommunications Research Institute 2011).

\footnotetext{
17 In particular for international roaming, it has no price controls because it is not yet present in Myanmar (ITU 2012a).
} 
In the development context of ICT, human resource development in the sector is a priority to help a country transform into a knowledge-based economy. It is in this light that the goal of eeducation and awareness in Myanmar should focus on achieving an inclusive e-Myanmar society, in which everyone has access to information services. The government aims to ensure that students are familiar with computers and are scientifically literate. It is collaborating with the private sector and local communities to establish multimedia classrooms and small computer laboratories in high schools; and IT learning centers, electronic resource centers, and computer training centers in colleges and universities. The Ministry of Education is also developing an educational intranet system linking all universities and colleges. And in cooperation with the Ministry of Information, it has launched a data broadcasting system for distance education, with more than 150 learning centers already established in multimedia high schools, colleges, universities, and institutes (ITU 2012a).

At the professional level, however, skilled ICT workers are in short supply. Although the number of training and research staff has steadily increased from 1995 to 2011, the number of enrollees and graduates in the computer courses in higher education institutes has declined from about 18,000 enrollees and 6,000 graduates in 2006-2007 to 10,000 enrollees and 4,000 graduates in 2010-2011 (Figure 3). If this trend continues, the current stock of ICT skills could cause disruptions to various ICT services.

The ICT Master Plan 2011-2015 highlights the following issues and constraints that deter the development of ICT skills and human capacity development including (i) low digital literacy, (ii) low intake of communication technology-related ICT education, (iii) lack of public training institutes, (iv) lack of software and education contents and technology, (v) unmet standards of global standard education, and (vi) brain drain as ICT professionals leave the country and work in Australia, Japan, Singapore, or Thailand.

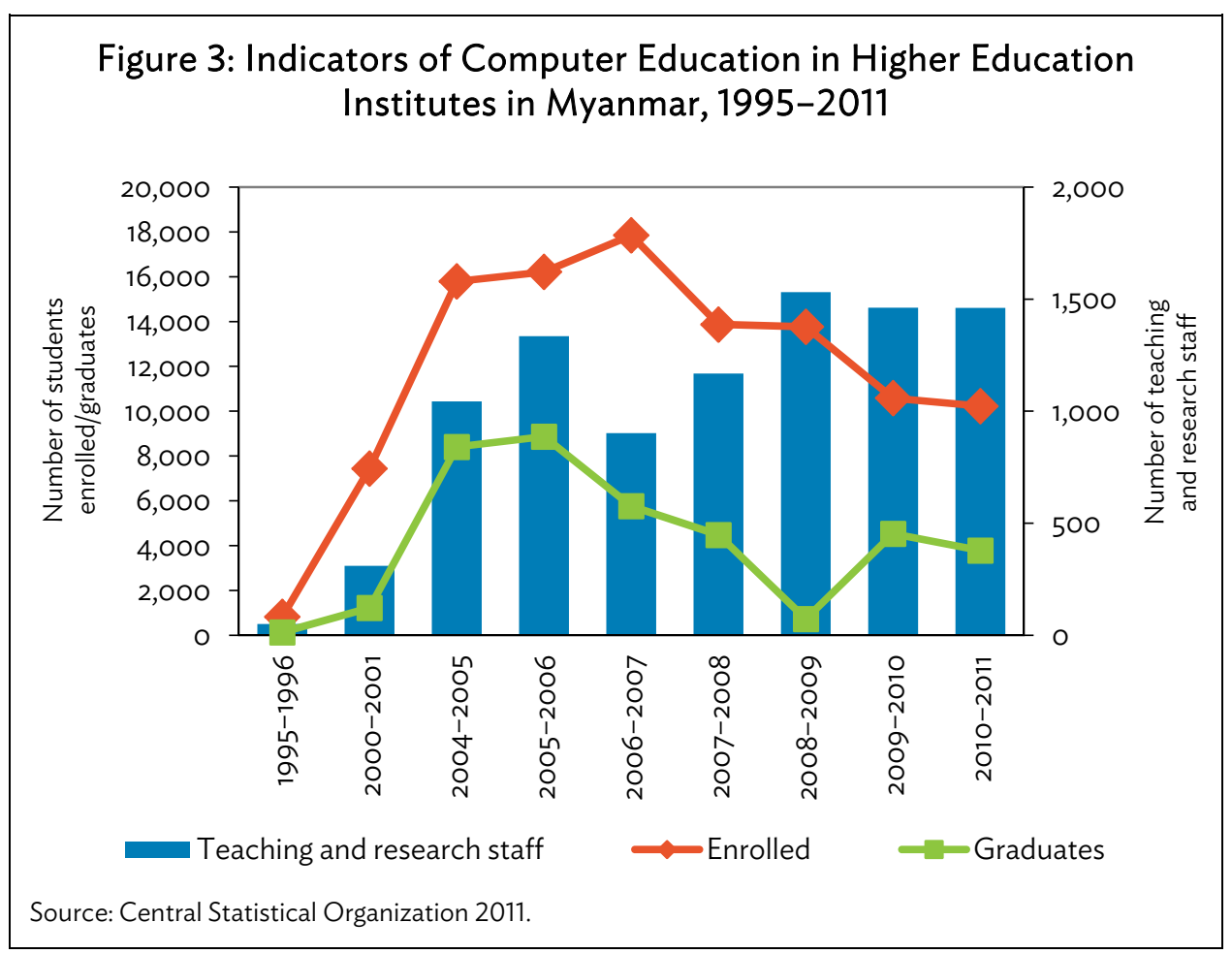




\section{B. Information and Communication Technology Industries}

Although ICT currently makes a minimal contribution to overall global trade and employment, ${ }^{18}$ the ICT private sector could become a potential driver of economic growth in Myanmar. The three most popular ICT businesses in the country are software development and training, hardware sales, and system integration. The software sector, which accounts for over $50 \%$ of total ICT businesses, would be the most immediate driver of ICT development in Myanmar (Orbicom and International Development Research Centre 2009).

The private sector in Myanmar's ICT industry faces a lack of capital, high turnover rates of experienced software developers, a lack of sophisticated ICT firms and a standardization body, poor ICT infrastructure, and high corporate tax and operations costs (Ministry of Communications, Posts and Telegraphs and Korea International Cooperation Agency 2011).

A 2010 survey commissioned by the government also highlighted the problems the ICT sector faces. These include the following:

(i) lack of facilities and research and development investment, which is delaying the industry's development;

(ii) policy demands on support for technology development, and technology introduction and transfer;

(iii) shortage of software developers and a highly skilled workforce with college degrees, and lack of technology development experience;

(iv) difficulties in selling products or services in domestic and overseas markets due to lack of marketing strategies and marketing specialists; and

(v) difficulty in getting financial support from financial institutions and the government for product development, facilities, and operations of ICT firms.

Local experts in the ICT industry cite similar issues as well as (i) a lack of awareness of ICT use, (ii) rapidly decreasing hardware retail prices, (iii) a high turnover rate of experienced ICT professionals, (iv) high corporation tax and no tax exemptions for the ICT business, and (v) poor telecommunications and energy infrastructure.

\section{Information and Communication Technology as an Enabler in Public Services: e-Governance}

As Myanmar reengages with the rest of the world, many sectors of the economy need to be revived and upgraded to global standards to achieve more inclusive and environmentally sustainable growth. This will require enhancing e-governance-supported service delivery and capacity building in core economic sectors. ${ }^{19}$

Myanmar continues to perform poorly on e-governance (Table A.9). Out of 193 countries, it ranked 175th in the United Nations e-Government Development Index in 2014, 15 places lower than in 2012. The country not only ranks lowest among countries in Southeast Asia, but its e-government

18 It accounted for just $0.02 \%$ of total goods exports in 2010 (World Bank, World Development Indicators).

19 E-government is defined as the use of ICT and its application by the government for the provision of information and public services to the people. 
development score of 0.19 is much lower than the regional average of 0.46 . The low score is attributable to the poor performance of the e-Government Development Index's online service and telecommunications infrastructure indexes, the first two of three components that make up the index. The online service index achieved a score of 0.02 in 2014, the lowest in Southeast Asia. The various stages of online service indicate there is no online participation between citizens and the government (which translates to a zero e-participation index). ${ }^{20}$ And the web presence of the government is limited to static information, such as links to regional and departmental agencies, or public documents, such as messages of heads of state and departments. The very low score (0.01 in 2014 and zero in 2012) of the telecommunications infrastructure index in the last two surveys suggests that computers, the internet, and e-mail are hardly used and not integrated in government business processes. The third component, the human capital index, scored 0.53 in 2014 and is comparable with the scores of other countries in Southeast Asia.

\section{INFORMATION AND COMMUNICATION TECHNOLOGY SECTOR CONSTRAINTS}

The ICT sector's slow development results from low investment, incomplete legal frameworks and policies, limited IT capacities, and ambiguous incentives to attract more players into the sector.

Myanmar's 2011-2015 ICT plan acknowledges several pressing ICT infrastructure-related problems. ${ }^{21}$ These include limited, outdated, and unstable telecommunications infrastructure and network systems, low average revenue per user in fixed services, and limited foreign investment. Industry-related issues identified in the plan include a weak ICT industry base, strict regulations imposed on these industries, and ICT knowledge and skills constraints, such as a mismatch of ICT manpower supply and demand, lack of skilled ICT professionals caused primarily by a brain drain, and the public's lack of ICT knowledge (Ministry of Communications, Posts, and Telegraphs and Korea International Cooperation Agency 2011).

Several external assessments raised similar issues, such as the underdeveloped hard ICT infrastructure and human capacity issues, as constraints of Myanmar's ICT sector. These assessments also highlighted the following critical issues affecting the sector: (i) multiple technologies without interconnection, (ii) expensive SIM cards (though this was resolved in 2014 with the price of SIM cards reduced to as low as $\$ 2$ ), (iii) the monopoly of Chinese vendors in equipment and handsets (DBS Vickers Securities 2013), and (iv) an outdated and inconsistent ICT legal framework (Orbicom and International Development Research Centre 2009). ${ }^{22}$ The following section deals with the constraints in need of immediate/priority attention.

20 Stage 1, the emerging presence stage, describes the government's online presence; this has limited and basic information on its web page and/or official website. Stage 2, the enhanced presence stage, provides greater public policy and governance sources of current and archived information, such as policies, laws and regulations, reports, newsletters, and downloadable databases. Stage 3, the transactional presence stage, allows two-way interaction between the citizen and his/her government. Stage 4, the connected presence stage, characterizes an integration of government-to-government, government-to-citizen, and citizen-to-government (and reverse) interactions.

21 This is a follow-up ICT master plan after the first two ICT master plans were drafted (2001-2005 ICT Master Plan and 2006-2010 ICT Master Plan and Action Plan).

22 In addition, in the context of e-government, the constraints are lack of skilled personnel, poor communications infrastructure, insufficient budget in operating information systems, electricity problems, resistance of users, and lack of awareness of government leaders (Orbicom and International Development Research Centre 2009). 


\section{A. Absence of a Separate and Independent Regulator}

The PTD's mandate as a regulator is mainly limited to telecommunications. The other subsectors continue to be regulated by different institutions or their concerns are not yet assigned to a specific ministry or department and, thus, issues that need immediate resolution are addressed in an ad hoc manner.

The need for a regulatory body is becoming more pressing as the ICT sector moves toward a free market regime. Although it is still perceived to be mainly under state control, the new Telecommunications Law requires that an independent regulator be established by 2015 (Ramamurthy 2013). The independent regulator will play a key role in the sector's ongoing process liberalization as well as ensuring that ICT services are provided efficiently at affordably. The transition of PTD to the Myanmar Telecommunications Commission, as the regulator will be called, will therefore require considerable capacity building for it to be able to perform all the functions mandated under the law.

\section{B. Inadequate Information and Communication Technology Legal Framework and Implementing Guidelines}

The slow implementation of legal and institutional frameworks and policies has affected liberalization in the sector. ICT is a very dynamic sector, which requires that the government and the sector's regulator immediately adopt policies and regulations to facilitate smooth operation of ICT services. To its credit, the government has updated some of its legal and institutional framework to help facilitate this, and it approved the new Telecommunications Law, which incorporates the legal framework for IT.

The immediate concern, however, is implementing the law's provisions; these need to be operationalized once the implementing rules and regulations are in place. It is worth highlighting that the existing legal framework for ICT was developed not via a systematic blueprint, but in response to temporary needs. Thus, continuous review and updating is needed to harmonize regulations amid technological developments and changes in the ICT market (Orbicom and International Development Research Centre 2009). For example, there is still no transparent and consistent spectrum policy or a mechanism for protecting assigned frequencies (and for monitoring this) following the recent liberalization of telecommunications and growth in mobile services and broadband. As part of the allocation of licenses to other operators, a clear allocation of spectrum will be vital to enabling the efficient provision of services to the market. The MPT's network needs to be reviewed to ensure all its operations migrate to their assigned network spectrum (Deloitte Southeast Asia 2012).

\section{Limited Foreign Investment}

The government has already put in place laws providing incentives to attract private investment and to maximize positive linkages from these investments. Despite this, and granting licenses to operate telecommunications-related services, foreign investment in the sector remains limited. Unless there is full liberalization, it will take time for foreign investors to become active in the sector. Moreover, the ambiguities in policies - such as in spectrum management, infrastructure sharing and interconnection, and the incentives themselves-could lead to a lack of transparency and corrupt practices, discouraging foreign investors. 


\section{Inadequate Physical Infrastructure to Support Information and Communication Technology Investments}

Poor domestic connectivity due to inadequate support infrastructure and insufficient stable supplies of power constrain the building of new ICT infrastructure and maintenance of existing infrastructure (Deloitte Southeast Asia 2012). The absence of reliable energy and transport infrastructure will also deter investors from financing technology infrastructure investments that can develop the ICT sector.

The country's existing telecommunications infrastructure also needs to be expanded and improved-using recent technological developments - to reach rural areas. Teledensity remains low and mobile subscriptions have not been able to catch up with growth in other Southeast Asian countries, due to cost-related issues. And, as noted, internet and telephone services are limited in villages across Myanmar. Investments, especially from the private sector, will be required to achieve the goals of the current ICT master plan.

\section{E. Skills Gap and Mismatch in Information and Communication Technology}

The lack of workers with higher ICT knowledge and skills in Myanmar is a major issue that needs to be addressed as ICT becomes an integral part of the development process. Few of the country's many IT graduates qualified to the standards set by IT companies. The exodus of qualified ICT professionals to Thailand, Japan, Australia, and Singapore compounds the problem. And while there has been increasing public awareness of ICT, general knowledge on the sector continues to be deficient especially on how ICT can bridge the digital divide between countries and therefore support the domestic economy.

Myanmar will require qualified ICT graduates to support the country's growth and its ability to leapfrog in development. An opinion survey of executives conducted in August-October 2008 by the Asia-Pacific Research and Training Network on Trade indicated that professional competency in selected ICT services was below average.

\section{RECOMMENDATIONS}

Myanmar is expected to grow at least 6.8\% per year in the coming years, given its potential and the level of investor interest from overseas. Accompanying this growth will be an increase in demand for infrastructure services, including ICT-related services, both for consumption and production uses. Inability to respond to this growing demand will constrain efforts to reach targeted growth and slow poverty alleviation. ICT will be a key factor in Myanmar's economic transformation. Using it effectively, the country should be able leapfrog economic development and leverage cost-efficient technology. It has already paved the way to the liberalization of the ICT sector by recently awarding highly contested licenses to two international operators in June 2013. This has signaled foreign investors that the ICT sector is ready to join the technology bandwagon.

It is also important for Myanmar to develop innovative financing mechanisms and modalities to allow the funding of ICT infrastructure investments, since developing countries may be unable to mobilize domestic resources to fund all the projects. This is where private sector financing comes in. But to attract private financing, there is a need to translate infrastructure requirements into financially viable and bankable projects. At the same time, the government is responsible for ensuring that policies and the regulatory environment is stable and that institutions managing the infrastructure 
sectors such as ICT are able to efficiently facilitate the development of the sector and enable it to contribute to the country's output.

Given rapid developments in the ICT sector, the following recommendations should be followed in the short- to medium-term to help achieve the objectives set out for the sector.

\section{Short- and Medium-Term Measures:}

1. Draft the rules and regulations to implement all provisions of the new Telecommunications Law, which covers the following key reform areas: (i) licensing, (ii) frequency and spectrum management, (iii) technical standards, (iv) consumer protection, (v) competitive practices, (vi) universal service, (vii) access and interconnection and infrastructure sharing, and (viii) transitional arrangements.

2. Develop a comprehensive plan to ensure the smooth transition of PTD to an independent regulatory body in terms of its financing, structure, regulatory functions including research, analysis and decision-making capabilities to help improve regulatory certainty, and plan for it to be updated to be always consistent with global best practices.

a. Establish a clear appointment process and selection criteria for the head and chairperson of PTD, and for its members and commissioners, or for the reorganized regulatory authority.

b. Prepare and implement a comprehensive program to strengthen PTD's capacity to perform its mandated functions.

c. Prepare and implement a plan of action to ensure that PTD will be able to perform its mandated functions within a timeframe specified under the new Telecommunications Law in the following areas:

(i) monitoring the quality of service standards, compliance with license conditions and regulatory obligations, conducting on-site inspections of networks and equipment, and accessing records related to revenue and market statistics;

(ii) handling dispute resolutions for interconnection, infrastructure sharing, spectrum disputes, and consumer complaints;

(iii) enforcing the rules and regulations in a transparent and nondiscriminatory manner to ensure that operators comply with laws, regulations, license conditions, and other obligations, including sanctions for violating laws, regulations, and license conditions; and

(iv) managing and overseeing the appeals process.

d. Provide accountability and transparency through the publication of annual reports and legislative and regulatory documents and public consultations before issuing regulatory decisions.

3. Further enhance market competition following the entry of foreign operators in the ICT sector. 
a. Coordinate network development with the new entrants to reduce capital expenditure, accelerate coverage expansion, and ensure existing infrastructure is fully utilized.

b. Establish licensing and regulatory policies encouraging competition and interoperability.

(i) Establish infrastructure- and network-sharing policies that can help operators save upfront on infrastructure development and operating costs (that is, allow sharing or lease of infrastructure for network establishment, such as backbone, backhaul, and steel tower that are currently owned by MPT).

(ii) Adopt symmetrical interconnection rates to ensure new players compete on a level playing field.

(iii) Allow subscribers to maintain their allotted mobile numbers when switching mobile phone providers.

(iv) Provide a technology-neutral regulatory environment by ensuring laws and regulations do not favor certain technologies or networks over others and allow providers to offer a wide range of services on the network or platform of their choice.

c. Promote transparency and accountability in the operations and interoperability of the sector players.

(i) Promote voluntary disclosure of technical information and development of consensus-based standards.

(ii) Publish pertinent documents that show interconnection agreements and prices and ensure accessibility to general public.

d. Increase customer accessibility by addressing affordability of ICT services.

(i) Rationalize subscription fees, allow for less restrictive distribution of inexpensive handsets and consider allowing a handset subsidy for those that cannot afford ICT services.

(ii) Consider lifting retail price controls to further lower costs of ICT services.

4. Rollout physical and network infrastructure that can meet current and future needs.

a. Ensure the rollout meets current needs while maintaining flexibility for future enhancements by installing electrical wiring and fiber cables at the same time to maximize capital expenditure.

b. Consider the geographical area and the needs of Myanmar's population in the provision of infrastructure to be rolled out; for example, $3 \mathrm{G}$ or $4 \mathrm{G}$ wireless for most urban and suburban areas, $2 \mathrm{G}$ network for rural areas, and satellite broadband for remote areas and highly mountainous terrains.

c. Coordinate with appropriate government agencies that can establish and ensure a stable supply of power to support various ICT initiatives. 
d. Setup the broadband infrastructure.

(i) Expedite action on the drafting and adoption of a national broadband policy to provide a framework to catalyze the development of the sector.

(ii) Review ICT policy to include broadband-related concerns and outline goals such as the deployment of a nationwide broadband infrastructure and promoting the adoption of broadband services, the provision of public services using broadband, and broadband services to specific populations.

e. Design and adopt effective polices for spectrum management.

(i) Review existing networks to ensure that all its operations are migrated to allocated network spectrum assigned to them.

(ii) Ensure there is sufficient trained manpower, as the process of allocating spectrum to free up blocks for other new operators requires engineering skills for planning and implementation.

(iii) Ensure competitive and transparent spectrum allocation with clear policies that guarantee fair distribution of bandwidth.

(iv) Allocate a substantive amount of low-frequency spectrum to minimize rollout costs.

(v) Adopt a spectrum plan that follows ITU methods for spectrum standardization, complies with international standards, and is common with the rest of the region to be in line with ASEAN integration and to help minimize future costs of rolling out a network.

5. Build the core infrastructure to support ICT education and training.

a. Require primary and secondary schools to offer ICT skills training and testing opportunities.

b. Ensure the efficient provision of software and hardware infrastructure (for example, free connection to internet) to schools and universities.

c. Give incentives and additional resources for providing ICT skills training to colleges and universities.

d. Ensure workers have the opportunity to strengthen their IT skills through ICT retraining and lifelong learning programs.

e. Ensure strict control on the quality of ICT education and training programs by continuous monitoring of the curriculum and pedagogy by a national authority such as the Ministry of Education.

6. Review and align the functions of all ICT-related institutions with mandates to ensure that master plans, strategies, and policies for the ICT sector's growth are integrated. 
a. Conduct an organizational review of the Ministry of Communications and Information Technology (MCIT), Computer Science Development Council (CSDC), and all attached agencies and departments in the ICT sector.

(i) Consolidate the functions of CSDC and its attached agencies, e-National Task Force, and Myanmar Computer Federation under MCIT's jurisdiction.

(ii) Strengthen the role of CSDC under the MCIT by assigning it functions to promote informatization policies and e-government initiatives.

(iii) Create a department or unit under the MCIT (for example, a department of communications) that will focus on the planning, implementation, and development of integrated communications systems (fixed line, mobile, and internet network).

(iv) Establish the MCIT as the body in charge of ICT development sector.

b. Facilitate the privatization of the MPT within the ambit of the new Telecommunications Law.

(i) Develop a policy framework including a time frame to guide privatization and commercialization efforts.

(ii) Strengthen corporate governance by recruiting members of top management that can make decisions that are clearly in the best interests of the MPT, the government, and key stakeholders.

(iii) Ensure the MPT operates with a consistent commercial mandate, free from political interference.

(iv) Impose hard budget constraints on the MPT to encourage service efficiency.

(v) Increase capacity within the MPT to manage the reform process.

(vi) Review and update or revise the State-Owned Economic Enterprises Law of 1989 to allow the MPT to perform its mandated tasks in line with international best practices.

(vii) Adopt a state-owned enterprises' reform strategy with the aim of developing a practical implementation plan based on existing technical gaps and implementation constraints.

7. Augment the budget for financing the expansion of network and infrastructure.

a. Scale up the budget for development, operation, and maintenance of ICT infrastructure by tapping the private sector through private-public partnerships or external financing.

b. Secure funds for infrastructure expansion and advancement through direct investments or investment from overseas communication service providers or vendor's investment in kind.

8. Promote ICT awareness and digital literacy.

a. Foster an informatization culture in both rural and urban areas.

(i) Set up marketing campaigns for informatization through promotions, exhibitions, and the media. 
(ii) Build free-of-charge information facilities and access centers.

(iii) Offer computer literacy and internet programs to unserved populations that have no access to proper schooling and training.

b. Boost accessibility in rural areas through universal access/service policies.

(i) Adopt a comprehensive universal access/service policy or rural telecommunications development policy.

(ii) Ensure Myanmar has an operational universal service fund where operators, government, and donors contribute to finance rural infrastructure.

c. Establish other financing mechanisms (for example, special rural access concessions and tax incentives) for providing universal access/service.

(i) Encourage operators to offer special or "stratified" tariffs to eligible subscribers.

(ii) Promote scheduled build-out where operators are given deployment schedules for sections of rural areas in exchange for licenses or incentives such as tax breaks and cheap spectrum.

9. Ensure the ICT workforce is competitive and that it meets industry demands.

a. Establish certification standards for ICT skills.

(i) Establish national skill certification centers patterned and aligned with bilateral, regional, and international certification programs, which must be passed to receive certification to practice.

(ii) Encourage academic institutions to provide coordinated IT curricula, courseware, and online collaboration tools that help students achieve certification in technologies.

(iii) Ensure harmonization of national standards with domestic and foreign skills requirements.

b. Ensure private sector involvement in ICT skills development.

(i) Institute a mechanism to allow for constant interaction and cooperation between the government, private sector, and university/training institutes to develop and design courses imparting appropriate and updated ICT knowledge and skills.

(ii) Encourage the private sector to establish training and testing centers to certify IT professionals.

(iii) Incentivize the private sector to provide support for ICT research and development and capacity building in the ICT sector.

10. Myanmar should also look at the experiences of economies such as the Republic of Korea, which have successfully developed their ICT sectors and adopt the appropriate strategies (see box on next page). 


\section{ICT as a Growth Engine: The Experience of the Republic of Korea}

The Republic of Korea stands out in information and communication technology (ICT) development in the Asia and Pacific. In 2011, it scored highest in the ICT Development Index, which assesses country performance on ICT infrastructure and uptake. A very high share of the Republic of Korea's population has access to ICT technologies (62\% in fixed telephone lines, $110 \%$ in mobile cellular services, $84 \%$ in internet, and 38\% in fixed broadband internet, all as of 2012). The country's remarkable performance in ICT-related indicators makes it an ideal case to study ICT-driven development that other countries can emulate.

\section{Key Success Factors}

Public consensus on digitalization as an engine for economic growth. In the 1990s, Korean society and the government decided to get ahead in informatization. The government chose ICT as the new engine for economic growth and made focused investments in this sector. A concerted effort was made to nurture the sector and digitize the nation. The government believed the early establishment of broadband infrastructure was the most important step in transition to a knowledge-based economy.

Development of long-term master plan and strategies. The Korea Information Infrastructure (KII) plan launched in 1995 led to the completion of fiber optic networks across the country and access by 1,400 rural areas to broadband networks by 2000. In building the KII test-bed and the KII-G (Government), the government invested $\$ 620$ million, $3.6 \%$ of the total investment in the KII from the private and public sector. The government established several master plans for developing an information society: (i) the Informatization Promotion Act (1995) was followed by the First Master Plan for Informatization Promotion (1996), (ii) Cyber Korea 21 (1998) to address the changing environment caused by the Asian financial crisis, and (iii) e-Korea Vision 2006 (2002) updated by Broadband IT Korea Vision 2007 (2003); and (iv) UKorea Master Plan. All these measures led to the construction of an advanced information infrastructure, the introduction of various information systems in public services (for example, a government service portal, an integrated social insurance information system, an e-procurement system) and in the private sector, as well as growth in the overall ICT industry.

Comprehensive and systematic implementation mechanism. The establishment of the Ministry of Information and Communication in 1994 and strengthening of the National Computerization Agency under the ministry's umbrella played a pivotal role in designing, implementing, and coordinating national ICT policies and e-government initiatives. Government organizations responsible for the informatization strategy were restructured; namely the Informatization Promotion Committee in 1996, which is chaired by the prime minister, and the Informatization Strategy Meeting (1998), chaired by the President. In 1996, the Informatization Promotion Fund ${ }^{a}$ allowed the reallocation of profits from ICT-related fields directly into the ICT sector, enabling focused investment in ICT. The informatization policies of different agencies and ministries were therefore effectively coordinated.

Public informatization training to create ICT demand. Public informatization training programs were offered by the government to bridge the digital divide and boost self-sustaining demand among a large segment of the population. From 2000 to 2002, the government ambitiously offered internet and computer literacy programs targeting 10 million people, including housewives, students, military personnel, the disabled, the elderly, and even prison inmates. Low-price computers allowed more people to gain access to the internet, and over 4,000 free-of-charge information facilities were set up across the country. All schools were connected with the internet for free or at discounted rates. As well as creating a huge demand and market for the ICT industry, these efforts put in place the vital human infrastructure for further developing the sector.

Free market, competitive environment spurred by deregulation. The government opened the broadband internet service market without regulation or controls over licensing and pricing. Having minimal regulatory measures encouraged facility-based competition among service providers. And increased competition put downward pressure on tariffs, which, in turn, led to an increase in demand for internet services.

a Contributions to the fund were from the government budget, telecommunications service operators (a certain amount of yearly revenue prescribed by their licenses), the auction price for radio wave frequency, and a dividend from Korea Telecom when it was government-owned company.

Sources: Information Solutions Group n.d.; International Telecommunication Union 2012b; Kim 2009; World Bank, World Development Indicators http://data.worldbank.org/data-catalog/world-development-indicators (accessed December 2013). 


\section{APPENDIX: INFORMATION AND COMMUNICATION TECHNOLOGY TABLES}

Table A.1: National Broadband Plans in Southeast Asia, 2014

\begin{tabular}{lcccccccccc}
\hline & BRU & CAM & INO & LAO & MAL & MYA & PHI & SIN & THA & VIE \\
\hline $\begin{array}{l}\text { National broadband plan } \\
\text { adopted }\end{array}$ & Yes & No & Yes & No & Yes & No & Yes & Yes & Yes & No \\
\hline
\end{tabular}

$\mathrm{BRU}=$ Brunei Darussalam, $\mathrm{CAM}=$ Cambodia, $\mathrm{INO}=$ Indonesia, $\mathrm{LAO}=$ Lao People's Democratic Republic, MAL = Malaysia, MYA = Myanmar, $\mathrm{PHI}=$ Philippines, $\mathrm{SIN}=$ Singapore, $\mathrm{THA}=$ Thailand, $\mathrm{VIE}=$ Viet Nam .

Source: International Telecommunication Union, World Telecommunication/ICT Regulatory Database. http://www.itu.int/net4/itud/icteye/AdvancedDataSearch.aspx (accessed September 2015). 
Table A.2: Regulatory Structure of ICT Sector in Southeast Asia

\begin{tabular}{|c|c|c|c|c|c|c|c|c|c|c|}
\hline & $\begin{array}{c}\text { Brunei } \\
\text { Darussalam }\end{array}$ & Cambodia & Indonesia & Lao PDR & Malaysia & Myanmar & Philippines & Singapore & Thailand & Viet Nam \\
\hline \multicolumn{11}{|l|}{$\begin{array}{l}\text { A. Regulatory } \\
\text { Authority }\end{array}$} \\
\hline $\begin{array}{l}\text { Separate telecom/ICT } \\
\text { regulator exists }\end{array}$ & Yes & Yes & Yes & Yes & Yes & No & Yes & Yes & Yes & Yes \\
\hline $\begin{array}{l}\text { Year separate } \\
\text { regulator created }\end{array}$ & 2003 & 2012 & 2003 & 2007 & 1998 & & 1979 & 1992 & 2010 & 2011 \\
\hline $\begin{array}{l}\text { Regulator also } \\
\text { regulates other } \\
\text { utilities }\end{array}$ & $\ldots$ & Yes & $\ldots$ & $\ldots$ & No & & $\ldots$ & Yes & No & No \\
\hline $\begin{array}{l}\text { Regulator } \\
\text { autonomous in } \\
\text { decision making }\end{array}$ & No & No & No & & Yes & No & Yes & Yes & Yes & Yes \\
\hline $\begin{array}{l}\text { Responsible for } \\
\text { approving the } \\
\text { budget of the } \\
\text { regulator }\end{array}$ & Ministry of Finance & Sector minister & & & $\begin{array}{l}\text { Sector } \\
\text { minister }\end{array}$ & & Congress & $\begin{array}{l}\text { Ministry of } \\
\text { Finance }\end{array}$ & Commissioners & \\
\hline $\begin{array}{l}\text { Sources of regulator's } \\
\text { budget and } \% \\
\text { financed from each } \\
\text { source }\end{array}$ & & & $\begin{array}{l}\text { Government } \\
\text { appropriation: } \\
\text { 100\% }\end{array}$ & & & & $\begin{array}{c}\text { Government } \\
\text { appropriation: } \\
100 \%\end{array}$ & $\begin{array}{c}\text { License fees: } \\
71 \% \\
\text { Numbering } \\
\text { fees: } 3 \% \\
\text { Spectrum fees: } \\
26 \%\end{array}$ & $\begin{array}{c}\text { License fees: } \\
50.8 \% \\
\text { Numbering fees: } \\
\text { 39.3\% Spectrum } \\
\text { fees: } 3.5 \% \\
\text { Regulatory fees: } \\
6.4 \%\end{array}$ & \\
\hline $\begin{array}{l}\text { Reporting } \\
\text { requirements of the } \\
\text { regulator }\end{array}$ & $\begin{array}{c}\text { Report to } \\
\text { Minister of } \\
\text { Communications }\end{array}$ & $\begin{array}{l}\text { Annual report } \\
\text { to the Sector } \\
\text { Ministry, } \\
\text { reports to } \\
\text { Ministry of } \\
\text { Economic and } \\
\text { Finance too }\end{array}$ & $\begin{array}{l}\text { Annual report } \\
\text { to the sector } \\
\text { ministry }\end{array}$ & & $\begin{array}{l}\text { Report to } \\
\text { legislature; } \\
\text { annual } \\
\text { report to } \\
\text { sector } \\
\text { ministry }\end{array}$ & & $\begin{array}{l}\text { Annual report } \\
\text { to the sector } \\
\text { ministry }\end{array}$ & $\begin{array}{l}\text { Annual report } \\
\text { to the sector } \\
\text { ministry }\end{array}$ & $\begin{array}{l}\text { Report to } \\
\text { legislature }\end{array}$ & $\begin{array}{l}\text { Annual } \\
\text { report to the } \\
\text { sector } \\
\text { ministry }\end{array}$ \\
\hline
\end{tabular}


Brunei

Darussalam

Cambodia

Indonesia

Lao PDR

Malaysia

Myanmar

Philippines

Singapore

Thailand

Viet Nam

B. Regulatory

unctions

Entity in charge of

licensing

Entity in charge of

R

interconnection

rates

Entity in charge of

price regulation

Entity in charge of

technical

standards setting

Entity in charge of

radio frequency

allocation and

assignment

Spectrum

monitoring and

enforcement

Entity in charge of numbering

Entity in charge of type approval

Entity in charge of service quality

monitoring

Entity in charge of universal

service/access

Quality of service

standards setting

Entity in charge of enforcement of quality of service

obligations

$S R \quad S O$

S R

$S$

...

$\mathrm{R}$

R

R

SOp M

Op

Op

Op

R Op M

$\mathrm{R}$

S

R

SOpM SO

R

S

R

R

R

S R

R

SOOpM SOp

N

R

R

R

S

R

R

SOM

S

S

R

R

R

SR

R

R

...

S

R

$S$

R

R

S R

R

SOp M

S

R

SOp

R

ON

R

SOp

$$
\text { R }
$$

N

S R Op

$N$

...

R

R

R

S R

S R

R Op M

R

Op

S R Op

SN

OM

SOp
SOp
...

R

$\cdots$

R

R

R

$S R$

SOp

SR 
Table A.2 continued

\begin{tabular}{|c|c|c|c|c|c|c|c|c|c|c|}
\hline & $\begin{array}{c}\text { Brunei } \\
\text { Darussalam }\end{array}$ & Cambodia & Indonesia & Lao PDR & Malaysia & Myanmar & Philippines & Singapore & Thailand & Viet Nam \\
\hline $\begin{array}{l}\text { Entity in charge of } \\
\text { broadcasting } \\
\text { (radio and TV } \\
\text { transmission) }\end{array}$ & & $\mathrm{O}$ & & & SR & SO & & 0 & $\mathrm{R}$ & $\mathrm{RM}$ \\
\hline $\begin{array}{l}\text { Entity in charge of } \\
\text { broadcasting } \\
\text { content }\end{array}$ & $S$ & $O M$ & $\ldots$ & $\ldots$ & $S R$ & $\mathrm{O}$ & $\ldots$ & O & $\mathrm{R}$ & $S R$ \\
\hline $\begin{array}{l}\text { Entity in charge of } \\
\text { information } \\
\text { technology }\end{array}$ & O & $S$ & $\ldots$ & $\ldots$ & $\mathrm{R}$ & SO & $\ldots$ & $\mathrm{R}$ & O & $S$ \\
\hline $\begin{array}{l}\text { Entity in charge of } \\
\text { internet content }\end{array}$ & $\mathrm{SO}$ & $\mathrm{N}$ & $\ldots$ & $\ldots$ & $\mathrm{R}$ & Op & $\ldots$ & O & $\mathrm{O}$ & $S R$ \\
\hline
\end{tabular}

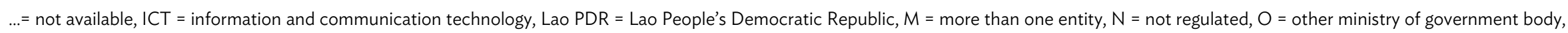
$\mathrm{Op}=$ operator, $\mathrm{R}=$ regulatory authority, $\mathrm{S}=$ sector ministry, $\mathrm{TV}=$ television.

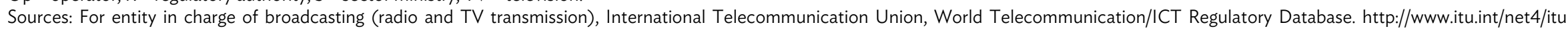

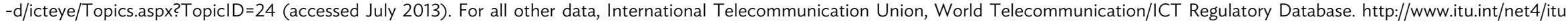
-d/icteye/AdvancedDataSearch.aspx (accessed September 2015). 
Table A.3: Infrastructure Sharing in Southeast Asia 2014

\begin{tabular}{|c|c|c|c|c|c|c|c|c|c|c|}
\hline & BRU & CAM & INO & LAO & MAL & MYA & $\mathrm{PHI}$ & SIN & THA & VIE \\
\hline $\begin{array}{l}\text { Infrastructure sharing for mobile } \\
\text { operators permitted }\end{array}$ & Yes & No & Yes & Yes & Yes & Yes & Yes & Yes & Yes & Yes \\
\hline $\begin{array}{l}\text { Infrastructure sharing mandated } \\
\text { (towers, base stations, posts, } \\
\text { ducts, etc.) }\end{array}$ & Yes & Yes & Yes & $\ldots$ & Yes & Yes & $\ldots$ & No & Yes & Yes \\
\hline
\end{tabular}

$\ldots=$ not available, $\mathrm{BRU}=$ Brunei Darussalam, $\mathrm{CAM}=$ Cambodia, $\mathrm{INO}=$ Indonesia, $\mathrm{LAO}=$ Lao People's Democratic Republic, $\mathrm{MAL}=\mathrm{Malaysia}$, MYA = Myanmar, $\mathrm{PHI}=$ Philippines, $\mathrm{SIN}=$ Singapore, $\mathrm{THA}=$ Thailand, $\mathrm{VIE}=\mathrm{Viet} \mathrm{Nam}$.

Source: International Telecommunication Union, World Telecommunication/ICT Regulatory Database. http://www.itu.int/net4/itud/icteye/AdvancedDataSearch.aspx (accessed September 2015).

\section{Table A.4: Spectrum Policy and Assignment in Southeast Asia}

\begin{tabular}{|c|c|c|c|c|c|c|c|c|c|c|}
\hline & BRU & CAM & INO & LAO & MAL & MYA & $\mathrm{PHI}$ & SIN & THA & VIE \\
\hline \multicolumn{11}{|l|}{ Spectrum Policy } \\
\hline Secondary trading ${ }^{a}$ allowed & $\mathrm{N}$ & $\mathrm{N}$ & $\ldots$ & & $\mathrm{N}$ & $\mathrm{N}$ & $\ldots$ & $\mathrm{Y}$ & $\mathrm{N}$ & $\mathrm{N}$ \\
\hline Band migration ${ }^{\mathrm{b}}$ allowed & $\ldots$ & N & $\ldots$ & $\ldots$ & Y & $\mathrm{N}$ & $\ldots$ & Y & Y & $\mathrm{N}$ \\
\hline $\begin{array}{l}\text { Information on spectrum } \\
\text { publicly available }\end{array}$ & $\mathrm{N}$ & N & $\ddot{Y}$ & N & $\mathrm{Y}$ & $\mathrm{N}$ & $\cdots$ & Y & $\mathrm{N}$ & Y \\
\hline \multicolumn{11}{|l|}{ Spectrum Assignment } \\
\hline Operators assigned spectrum & $\ldots$ & Y & $\ldots$ & $\mathrm{Y}$ & $\mathrm{Y}$ & $\mathrm{Y}$ & $\ldots$ & $\mathrm{Y}$ & $\mathrm{Y}$ & $\mathrm{Y}$ \\
\hline $\begin{array}{l}\text { Number of operators that } \\
\text { have been licensed }\end{array}$ & & 6 & & & 4 & 1 & & 3 & 1 & \\
\hline \multicolumn{11}{|l|}{ WiMax } \\
\hline Operators assigned spectrum & $\ldots$ & Y & $\ldots$ & $\ldots$ & $\mathrm{Y}$ & $\mathrm{Y}$ & $\ldots$ & $\mathrm{Y}$ & $\mathrm{N}$ & $\mathrm{N}$ \\
\hline $\begin{array}{l}\text { Number of operators that } \\
\text { have been licensed }\end{array}$ & & & & & 3 & 0 & & 5 & & \\
\hline \multicolumn{11}{|l|}{ LTE } \\
\hline Operators assigned spectrum & $\ldots$ & Y & $\ldots$ & $\ldots$ & N & $\mathrm{Y}$ & $\ldots$ & $\mathrm{Y}$ & $\mathrm{N}$ & $\mathrm{N}$ \\
\hline $\begin{array}{l}\text { Number of operators that } \\
\text { have been licensed }\end{array}$ & & 2 & & & & & & 5 & & \\
\hline
\end{tabular}

... not available, $B R U=$ Brunei Darussalam, $C A M=$ Cambodia, IMT = international mobile telecommunications, INO = Indonesia, $L A O=$ Lao People's Democratic Republic, LTE = long term evolution, MAL = Malaysia, MYA = Myanmar, N = no, PHI = Philippines, $\mathrm{SIN}=$ Singapore, $\mathrm{THA}=$ Thailand, $\mathrm{VIE}=$ Viet Nam, WiMax = Worldwide Interoperability for Microwave Access, $\mathrm{Y}=$ yes.

a Secondary trading is the trading of spectrum rights or licenses between buyers and sellers directly without having it pass through the regulatory authority.

b Band migration is the right to use existing licensed spectrum for the provision of new services (for example, $2 \mathrm{G}$ spectrum used for $3 \mathrm{G}$ ).

Sources: For number of operators that have been licensed, International Telecommunication Union, World Telecommunication/ICT Regulatory Database. http://www.itu.int/net4/itu-d/icteye/Topics.aspx?TopiclD=24 (accessed July 2013). For other data, International Telecommunication Union, ICT Regulatory Database. http://www.itu.int/net4/itu-d/icteye/AdvancedDataSearch.aspx (accessed September 2015).

\section{Table A.5: Voice over Internet Protocol in Southeast Asia}

\begin{tabular}{|c|c|c|c|c|c|c|c|c|c|c|}
\hline & BRU & CAM & INO & $\mathrm{LAO}$ & MAL & MYA & $\mathrm{PHI}$ & SIN & THA & VIE \\
\hline $\begin{array}{l}\text { Individual users allowed to use } \\
\text { VolP }\end{array}$ & $Y$ & $Y$ & $\ldots$ & $\ldots$ & $Y$ & $N$ & $\ldots$ & $Y$ & $Y$ & $Y$ \\
\hline $\begin{array}{l}\text { Specific VolP policies or } \\
\text { regulations in place }\end{array}$ & $\mathrm{N}$ & $Y$ & $\ldots$ & $\mathrm{N}$ & $\mathrm{N}$ & $\mathrm{N}$ & $\ldots$ & $Y$ & Y & $\mathrm{N}$ \\
\hline
\end{tabular}

... = not available, $\mathrm{BRU}=$ Brunei Darussalam, $\mathrm{CAM}=$ Cambodia, $\mathrm{INO}=$ Indonesia, $\mathrm{LAO}=$ Lao People's Democratic Republic, $\mathrm{MAL}=\mathrm{Malaysia}$, MYA = Myanmar, $\mathrm{PHI}=$ Philippines, $\mathrm{SIN}=$ Singapore, $\mathrm{THA}=$ Thailand, $\mathrm{VIE}=$ Viet Nam, $\mathrm{VoIP}=$ voice over internet protocol.

Source: International Telecommunication Union, World Telecommunication/ICT Regulatory Database. http://www.itu.int/net4/itud/icteye/AdvancedDataSearch.aspx (accessed September 2015). 
Table A.6: Universal Access/Service of ICT Sector in Southeast Asia

\begin{tabular}{|c|c|c|c|c|c|c|c|c|c|c|}
\hline & $\begin{array}{c}\text { Brunei } \\
\text { Darussalam }\end{array}$ & Cambodia & Indonesia & Lao PDR & Malaysia & Myanmar & Philippines & Singapore & Thailand & Viet Nam \\
\hline $\begin{array}{l}\text { Universal access/service } \\
\text { policy adopted }\end{array}$ & $\mathrm{N}$ & $\mathrm{N}$ & $\ldots$ & $\ldots$ & $\mathrm{Y}$ & $\mathrm{N}$ & $\ldots$ & $\mathrm{Y}$ & $\mathrm{Y}$ & $\mathrm{N}$ \\
\hline $\begin{array}{l}\text { Definition of universal } \\
\text { access/service exists }\end{array}$ & $\mathrm{N}$ & Y & Y & $\mathrm{Y}$ & Y & $\mathrm{Y}$ & Y & Y & Y & $\mathrm{N}$ \\
\hline $\begin{array}{l}\text { Operators under universal } \\
\text { access/service obligation }\end{array}$ & $\begin{array}{c}\text { All } \\
\text { network/facilities } \\
\text {-based } \\
\text { operators, all } \\
\text { service-based } \\
\text { providers }\end{array}$ & $\begin{array}{c}\text { No obligation } \\
\text { due to } \\
\text { nonadoption } \\
\text { of universal } \\
\text { service } \\
\text { obligation }\end{array}$ & $\ldots$ & $\begin{array}{c}\text { All } \\
\text { network/fac } \\
\text { ilities-based } \\
\text { operators }\end{array}$ & $\begin{array}{c}\text { None, } \\
\text { obligations } \\
\text { are allocated } \\
\text { on a } \\
\text { competitive } \\
\text { basis }\end{array}$ & $\begin{array}{c}\text { All } \\
\text { operators }\end{array}$ & $\ldots$ & $\begin{array}{l}\text { Incumbent } \\
\text { fixed line } \\
\text { operator(s) }\end{array}$ & $\begin{array}{l}\text { Designated } \\
\text { universal service } \\
\text { provider }\end{array}$ & $\begin{array}{c}\text { All } \\
\text { network/facil } \\
\text { ities-based } \\
\text { operators }\end{array}$ \\
\hline $\begin{array}{l}\text { Voice services included in } \\
\text { universal access/service } \\
\text { definition }\end{array}$ & $\begin{array}{l}\text { Fixed line private } \\
\text { residential, fixed } \\
\text { line public } \\
\text { payphone, } \\
\text { individual mobile } \\
\text { cellular service, } \\
\text { public mobile } \\
\text { payphone }\end{array}$ & $\begin{array}{l}\text { Individual } \\
\text { mobile cellular } \\
\text { service }\end{array}$ & $\begin{array}{l}\text { Fixed line } \\
\text { public } \\
\text { payphone }\end{array}$ & $\begin{array}{l}\text { Fixed line } \\
\text { private } \\
\text { residential, } \\
\text { fixed line } \\
\text { public } \\
\text { payphone }\end{array}$ & $\begin{array}{l}\text { Fixed line } \\
\text { private } \\
\text { residential, } \\
\text { fixed line } \\
\text { public } \\
\text { payphone, } \\
\text { individual } \\
\text { mobile } \\
\text { cellular }\end{array}$ & $\begin{array}{l}\text { Fixed line } \\
\text { private } \\
\text { residential }\end{array}$ & $\begin{array}{l}\text { Fixed line } \\
\text { public } \\
\text { payphone } \\
\text { service, } \\
\text { accessibility } \\
\text { of telephone } \\
\text { service from } \\
\text { any } \\
\text { populated } \\
\text { area of the } \\
\text { country, basic } \\
\text { telephony }\end{array}$ & $\begin{array}{l}\text { Fixed line } \\
\text { private } \\
\text { residential, } \\
\text { fixed line } \\
\text { public } \\
\text { payphone }\end{array}$ & $\begin{array}{l}\text { Fixed line public } \\
\text { payphone, } \\
\text { individual mobile } \\
\text { cellular }\end{array}$ & $\begin{array}{l}\text { Fixed line } \\
\text { private } \\
\text { residential, } \\
\text { fixed line } \\
\text { public } \\
\text { payphone }\end{array}$ \\
\hline $\begin{array}{l}\text { VolP providers under universal } \\
\text { access/service }\end{array}$ & Y & $\mathrm{N}$ & $\ldots$ & $\ldots$ & Y & $\mathrm{N}$ & $\ldots$ & $\mathrm{N}$ & $\mathrm{N}$ & $\mathrm{N}$ \\
\hline $\begin{array}{l}\text { Other services included in } \\
\text { universal access/service }\end{array}$ & $\begin{array}{c}\text { Telecenters, } \\
\text { emergency } \\
\text { services, } \\
\text { directory services }\end{array}$ & $\begin{array}{l}\text { Schools } \\
\text { (primary, } \\
\text { secondary, } \\
\text { postsecondary }\end{array}$ & Telecenters & Telecenters & $\begin{array}{l}\text { Telecenters, } \\
\text { services } \\
\text { impaired/ } \\
\text { elderly }\end{array}$ & Telecenters & $\begin{array}{l}\text { Emergency } \\
\text { services }\end{array}$ & $\begin{array}{l}\text { Emergency } \\
\text { services, } \\
\text { directory } \\
\text { services, } \\
\text { telecenters }\end{array}$ & $\begin{array}{l}\text { Telecenters, } \\
\text { schools (primary, } \\
\text { secondary, } \\
\text { postsecondary),h } \\
\text { ealth centers, } \\
\text { services for } \\
\text { impaired/elderly }\end{array}$ & $\begin{array}{c}\text { Telecenters, } \\
\text { emergency } \\
\text { services, } \\
\text { directory } \\
\text { services }\end{array}$ \\
\hline Is USF in place & $\ldots$ & $\ldots$ & .. & $\ldots$ & Y & $\mathrm{N}$ & $\ldots$ & $\mathrm{N}$ & ... & Y \\
\hline Operational USF in place & $\mathrm{N}$ & $\mathrm{N}$ & Y & $\mathrm{N}$ & Y & $\mathrm{N}$ & $\ldots$ & $\mathrm{N}$ & Y & Y \\
\hline USF financed by other sources & $\ldots$ & $\ldots$ & $\mathrm{N}$ & $\ldots$ & $\mathrm{N}$ & $\mathrm{N}$ & $\ldots$ & $\ldots$ & $\mathrm{N}$ & $Y$ \\
\hline $\begin{array}{l}\text { Other financing mechanisms } \\
\text { for the provision of universal } \\
\text { service }\end{array}$ & $\mathrm{N}$ & $\mathrm{N}$ & $\mathrm{N}$ & $Y$ & $\mathrm{~N}$ & $\mathrm{~N}$ & $\ldots$ & $Y$ & $\mathrm{~N}$ & $\mathrm{~N}$ \\
\hline
\end{tabular}

... = not available, ICT = information and communication technology, Lao PDR = Lao People's Democratic Republic, $N=$ no, USF $=$ universal service fund, $V$ olP $=$ voice over internet protocol, $Y=$ yes. Source: International Telecommunication Union, World Telecommunication/ICT Regulatory Database. http://www.itu.int/net4/itu-d/icteye/AdvancedDataSearch.aspx (accessed September 2015). 
Table A.7: Enforcement, Dispute Resolution and Appeals of ICT Sector in Southeast Asia

\begin{tabular}{|c|c|c|c|c|c|c|c|c|c|c|}
\hline & $\begin{array}{c}\text { Brunei } \\
\text { Darussalam }\end{array}$ & Cambodia & Indonesia & Lao PDR & Malaysia & Myanmar & Philippines & Singapore & Thailand & Viet Nam \\
\hline $\begin{array}{l}\text { Regulator has } \\
\text { enforcement power }\end{array}$ & Yes & Yes & Yes & $\ldots$ & Yes & Yes & $\ldots$ & Yes & Yes & Yes \\
\hline $\begin{array}{l}\text { Public consultations } \\
\text { mandatory before } \\
\text { regulatory decisions }\end{array}$ & Yes & Yes & $\ldots$ & $\ldots$ & Yes & No & $\ldots$ & $\begin{array}{l}\text { In certain } \\
\text { cases }\end{array}$ & Yes & $\begin{array}{l}\text { In certain } \\
\text { cases }\end{array}$ \\
\hline $\begin{array}{l}\text { Appeals to regulatory } \\
\text { decisions allowed }\end{array}$ & Yes & Yes & $\ldots$ & $\ldots$ & Yes & Yes & $\ldots$ & Yes & Yes & Yes \\
\hline $\begin{array}{l}\text { Ultimate authority able to } \\
\text { overturn a regulatory } \\
\text { decision }\end{array}$ & Sector minister & $\begin{array}{l}\text { Sector } \\
\text { ministry, } \\
\text { Judiciary }\end{array}$ & Judiciary & $\ldots$ & Appeal tribunal & $\begin{array}{l}\text { Sector } \\
\text { ministry }\end{array}$ & Judiciary & $\begin{array}{l}\text { Sector } \\
\text { ministry }\end{array}$ & Judiciary & $\begin{array}{l}\text { Sector } \\
\text { ministry/ } \\
\text { Judiciary }\end{array}$ \\
\hline $\begin{array}{l}\text { Sanctions or penalties } \\
\text { imposed by regulator }\end{array}$ & $\begin{array}{l}\text { Monetary fines, } \\
\text { additional } \\
\text { license } \\
\text { obligation, } \\
\text { modification of } \\
\text { licenses, } \\
\text { licenses } \\
\text { suspension, } \\
\text { license } \\
\text { revocation }\end{array}$ & $\begin{array}{l}\text { Monetary } \\
\text { fines, } \\
\text { additional } \\
\text { license } \\
\text { obligations, } \\
\text { modification } \\
\text { of license, } \\
\text { license } \\
\text { suspension, } \\
\text { license } \\
\text { revocation }\end{array}$ & $\begin{array}{l}\text { Modification } \\
\text { of license, } \\
\text { license } \\
\text { suspension, } \\
\text { license } \\
\text { revocation }\end{array}$ & $\ldots$ & $\begin{array}{l}\text { Monetary fines, } \\
\text { imprisonment, } \\
\text { forfeiture }\end{array}$ & $\begin{array}{l}\text { Monetary } \\
\text { fines, } \\
\text { license } \\
\text { suspension }\end{array}$ & $\begin{array}{l}\text { Monetary } \\
\text { fines, } \\
\text { modification } \\
\text { of license, } \\
\text { license } \\
\text { revocation }\end{array}$ & $\begin{array}{l}\text { Monetary } \\
\text { fines, } \\
\text { additional } \\
\text { license } \\
\text { obligations, } \\
\text { modification } \\
\text { of license, } \\
\text { license } \\
\text { suspension, } \\
\text { license } \\
\text { revocation }\end{array}$ & $\begin{array}{c}\text { Monetary } \\
\text { fines, license } \\
\text { suspension, } \\
\text { license } \\
\text { revocation }\end{array}$ & $\begin{array}{l}\text { Monetary } \\
\text { fines, } \\
\text { license } \\
\text { suspension }\end{array}$ \\
\hline $\begin{array}{c}\text { Regulator responsible for } \\
\text { consumer complaints }\end{array}$ & Yes & Yes & Yes & $\ldots$ & Yes & No & $\ldots$ & Yes & Yes & Yes \\
\hline
\end{tabular}

$\ldots$... not available, ICT = information and communication technology, Lao PDR = Lao People's Democratic Republic.

Source: International Telecommunication Union, World Telecommunication/ICT Regulatory Database. http://www.itu.int/net4/itu-d/icteye/AdvancedDataSearch.aspx (accessed September 2015). 
Table A.8: Affordability Indicators and Price Controls, 2012

\begin{tabular}{|c|c|c|c|c|c|c|c|c|c|c|}
\hline & BRU & CAM & INO & $\mathrm{LAO}$ & MAL & MYA & $\mathrm{PHI}$ & SIN & THA & VIE \\
\hline \multicolumn{11}{|l|}{ Affordability indicators } \\
\hline $\begin{array}{l}\text { Fixed telephone sub-basket } \\
\qquad(\$ \text { a month }), 2010\end{array}$ & 11.7 & 7.4 & 5 & 4 & 5.1 & 0.9 & 15.3 & 8.2 & 8.8 & 2.4 \\
\hline $\begin{array}{l}\text { Mobile cellular sub-basket } \\
\quad \text { (\$ a month), } 2010\end{array}$ & 15.7 & 6.7 & 7.8 & 6.3 & 7.5 & 12.8 & 10.1 & 8.1 & 8.7 & 5.4 \\
\hline $\begin{array}{l}\text { Fixed broadband sub-basket } \\
\text { (\$ a month), } 2010\end{array}$ & 50.5 & 47 & 21.6 & 139.7 & 20.5 & 28.5 & 21.9 & 26.7 & 18.9 & 10.5 \\
\hline \multicolumn{11}{|l|}{ Internet telephony services, 2013} \\
\hline Pay-as-you-go (\$ a minute) & 0.16 & 0.27 & 0.04 & 0.13 & 0.02 & 0.41 & 0.2 & 0.02 & 0.07 & 0.34 \\
\hline Subscriptions ( $\$$ a month) & 2.8 & 12.5 & 5 & 6.3 & 1.1 & 17.5 & 7 & 1.1 & 1.8 & 8.2 \\
\hline SMS (\$ per message) & 0.1 & 0.1 & 0.14 & 0.1 & 0.1 & 0.1 & 0.07 & 0.1 & 0.06 & 0.07 \\
\hline \multicolumn{11}{|l|}{$\begin{array}{l}\text { Price control present } \\
\text { Fixed wired services }\end{array}$} \\
\hline Local voice & Y & $\mathrm{N}$ & $\mathrm{N}$ & $\mathrm{N}$ & Y & $Y$ & $\ldots$ & $\mathrm{N}$ & $\mathrm{N}$ & Y \\
\hline International voice & Y & $\mathrm{N}$ & $\mathrm{N}$ & $\ldots$ & $\mathrm{N}$ & $\mathrm{N}$ & $\ldots$ & $\mathrm{N}$ & $\mathrm{N}$ & Y \\
\hline Internet access & $\mathrm{N}$ & $\mathrm{N}$ & $\mathrm{N}$ & $\ldots$ & Y & Y & $\ldots$ & $\ldots$ & $\mathrm{N}$ & $\mathrm{N}$ \\
\hline \multicolumn{11}{|l|}{ Mobile wireless services } \\
\hline National long distance (voice) & Y & $\mathrm{N}$ & $\mathrm{N}$ & $\ldots$ & Y & $\mathrm{Y}$ & $\ldots$ & $\mathrm{N}$ & $\mathrm{N}$ & $\mathrm{N}$ \\
\hline International roaming (voice, SMS) & $\mathrm{N}$ & $\mathrm{N}$ & $\mathrm{N}$ & $\ldots$ & $\mathrm{N}$ & $\mathrm{N}$ & $\ldots$ & $\mathrm{N}$ & $\mathrm{N}$ & $\mathrm{N}$ \\
\hline Voice & $\mathrm{N}$ & Y & $\mathrm{N}$ & $\ldots$ & $\mathrm{N}$ & Y & $\ldots$ & $\mathrm{N}$ & Y & Y \\
\hline National roaming (voice, SMS) & $\mathrm{N}$ & $\mathrm{N}$ & $\mathrm{N}$ & $\ldots$ & $\mathrm{N}$ & Y & $\ldots$ & $\mathrm{N}$ & $\mathrm{N}$ & Y \\
\hline Fixed broadband & $N$ & $\mathrm{~N}$ & $\mathrm{~N}$ & $\ldots$ & $\mathrm{N}$ & Y & $\ldots$ & $\mathrm{N}$ & $\mathrm{N}$ & Y \\
\hline
\end{tabular}

$\ldots=$ not available, $\mathrm{BRU}=$ Brunei Darussalam, $\mathrm{CAM}=$ Cambodia, $\mathrm{INO}=$ Indonesia, $\mathrm{LAO}=$ Lao People's Democratic Republic, $M A L=$ Malaysia, $\mathrm{MYA}=\mathrm{Myanmar}, \mathrm{N}=\mathrm{no}$, $\mathrm{PHI}=$ Philippines, $\mathrm{SIN}=$ Singapore, $\mathrm{SMS}=$ short message service, $\mathrm{THA}=$ Thailand, VIE = Viet Nam, Y = yes.

Notes: Fixed telephone sub-basket refers to the monthly price charged for subscribing to the public switched telephone network, plus the cost of 30 local calls to the same (fixed) network (15 peak and 15 off-peak calls) of three minutes each. The service refers to the traditional fixed telephone line and not, for example, to prices for managed voice over

internet protocol. Mobile cellular sub-basket refers to the price of a standard basket of mobile monthly usage for 30 outgoing calls per month (on-net and off-net to a fixed line and for peak and off-peak times) in predetermined ratios, plus 100 short message service messages. The mobile cellular sub-basket is based on prepaid tariffs, although postpaid tariffs may be used for countries where prepaid subscriptions make up less than $3 \%$ of all mobile cellular subscriptions. The mobile cellular prepaid sub-basket is largely based on (but does not entirely follow) the 2009 methodology of the Organisation for Economic Co-operation and Development's low-user basket. Fixed broadband sub-basket refers to the price of the monthly subscription to an entry-level fixed broadband plan. For comparability reason, the fixed broadband sub-basket is based on a monthly usage of a minimum of 1 gigabyte. For plans that limit the monthly amount of data transferred by including caps below 1 gigabyte, the cost for additional bytes is added to the sub-basket. The minimum speed of a broadband connection is 256 kilobits per second.

Sources: World Bank and International Telecommunication Union 2012, and Skype for affordability indicators. 
Table A.9: E-Governance Indicators

\begin{tabular}{|c|c|c|c|c|c|c|c|c|c|c|c|c|c|c|c|c|c|}
\hline \multicolumn{17}{|c|}{ E-Government Development Index } & \multirow{3}{*}{$\begin{array}{c}\text { E- } \\
\text { Participation } \\
\text { Index }\end{array}$} \\
\hline & \multicolumn{5}{|c|}{ E-Government Development Index } & \multicolumn{6}{|c|}{ Components } & \multicolumn{5}{|c|}{ Online Service Index, 2014} & \\
\hline & \multicolumn{2}{|c|}{ Score } & \multicolumn{2}{|c|}{ Rank } & \multirow[b]{2}{*}{ Change } & \multicolumn{2}{|c|}{$\begin{array}{l}\text { Online } \\
\text { service }\end{array}$} & \multicolumn{2}{|c|}{$\begin{array}{c}\text { Telecom } \\
\text { Infra }\end{array}$} & \multicolumn{2}{|c|}{$\begin{array}{l}\text { Human } \\
\text { Capital }\end{array}$} & \multirow[t]{2}{*}{$\begin{array}{c}\text { Stage } \\
1 \%\end{array}$} & \multirow[t]{2}{*}{$\begin{array}{c}\text { Stage } \\
\text { II \% }\end{array}$} & \multirow[t]{2}{*}{$\begin{array}{l}\text { Stage } \\
\text { III \% }\end{array}$} & \multirow[t]{2}{*}{$\begin{array}{l}\text { Stage } \\
\text { IV \% }\end{array}$} & \multirow[t]{2}{*}{ Total \% } & \\
\hline & 2014 & 2012 & 2014 & 2012 & & 2014 & 2012 & 2014 & 2012 & 2014 & 2012 & & & & & & \\
\hline Singapore & 0.91 & 0.85 & 3 & 10 & +7 & 0.99 & 1.00 & 0.88 & 0.69 & 0.85 & 0.85 & 100 & 89 & 88 & 71 & 87 & 0.90 \\
\hline $\begin{array}{l}\text { Malaysia } \\
\text { Brunei }\end{array}$ & 0.61 & 0.67 & 52 & 40 & -12 & 0.68 & 0.79 & 0.45 & 0.45 & 0.71 & 0.77 & 84 & 73 & 40 & 50 & 61 & 0.53 \\
\hline Darussalam & 0.50 & 0.63 & 86 & 54 & -32 & 0.36 & 0.59 & 0.37 & 0.46 & 0.78 & 0.83 & 34 & 39 & 28 & 38 & 35 & 0.06 \\
\hline Philippines & 0.48 & 0.51 & 95 & 88 & -7 & 0.48 & 0.50 & 0.25 & 0.21 & 0.71 & 0.83 & 84 & 57 & 19 & 24 & 44 & 0.57 \\
\hline Viet Nam & 0.47 & 0.52 & 99 & 83 & -16 & 0.42 & 0.42 & 0.38 & 0.34 & 0.61 & 0.74 & 78 & 50 & 16 & 18 & 39 & 0.49 \\
\hline Thailand & 0.46 & 0.51 & 102 & 92 & -10 & 0.44 & 0.51 & 0.28 & 0.24 & 0.66 & 0.78 & 94 & 34 & 14 & 35 & 41 & 0.55 \\
\hline Indonesia & 0.45 & 0.49 & 106 & 97 & -9 & 0.36 & 0.50 & 0.31 & 0.19 & 0.68 & 0.80 & 69 & 34 & 9 & 35 & 35 & 0.29 \\
\hline Cambodia & 0.30 & 0.29 & 139 & 155 & +16 & 0.17 & 0.19 & 0.21 & 0.08 & 0.52 & 0.60 & 50 & 18 & 5 & 9 & 19 & 0.20 \\
\hline Lao PDR & 0.27 & 0.29 & 152 & 153 & +1 & 0.14 & 0.22 & 0.16 & 0.10 & 0.49 & 0.57 & 50 & 14 & 2 & 6 & 16 & 0.20 \\
\hline Myanmar & 0.19 & 0.27 & 175 & 160 & -15 & 0.02 & 0.10 & 0.01 & 0.00 & 0.53 & 0.71 & 13 & 11 & 0 & 3 & 7 & 0.08 \\
\hline $\begin{array}{l}\text { Southeast } \\
\text { Asia }\end{array}$ & & & & & & & & & & & & & & & & & \\
\hline average & 0.46 & 0.50 & & & & 0.41 & 0.48 & 0.33 & 0.28 & 0.65 & 0.75 & & & & & & 0.42 \\
\hline
\end{tabular}

Lao PDR = Lao People's Democratic Republic.

Sources: United Nations 2014; United Nations 2012. 


\section{REFERENCES}

Central Statistical Organization. 2011. Myanmar Data. CD-ROM.

DBS Vickers Securities. 2013. Regional Industry Focus: Asian Telecom Sector. DBS Group Research. 10 April. http://dealer.affinhwang.com/Archive-CompanyFocus/HwangDBS\%20Vickers\%20 Research/2.\%20Sector\%20Focus/2013\%20Sector\%20Focus/Myanmar\%20Telecom\%202013 0410\%20(Regional).pdf

Deloitte Southeast Asia. 2012. Myanmar: The Next Asian Telecommunications Greenfield? Yangon.

Freedom House. 2012. Freedom on the Net: A Global Assessment of Internet and Digital Media. Washington, DC.

2013. Freedom on the Net: A Global Assessment of Internet and Digital Media. Washington, DC.

Information Solutions Group. n.d. ICT as a Key Engine for Development: Good Practices and Lessons Learned from Korea.

International Telecommunication Union (ITU). 2012a. Wireless Broadband Masterplan for the Union of Myanmar. https://www.itu.int/pub/D-THEM-01-2012

2012b. Measuring the Information Society. Geneva.

2014. World Telecommunication/ICT Indicators Database 2014. CD-ROM.

I ICT Statistics. http://www.itu.int/en/ITU-D/Statistics/Pages/stat/default.aspx

- World Telecommunication/ICT Regulatory Database. http://www.itu.int/net4/itu-d/ icteye/AdvancedDataSearch.aspx and http://www.itu.int/net4/itu-d/icteye/Topics.aspx?Topic $I D=24$

Kim, D. 2009. Korean Experience of Overcoming Economic Crisis through ICT Development. ESCAP Technical Paper. Bangkok: United Nations ESCAP.

McKinsey Global Institute. 2013. Myanmar's Moment: Unique Opportunities, Major Challenges. New York: McKinsey \& Company.

Ministry of Communications and Information Technology (MCIT). http://www.mcit.gov.mm/ptd -about (in Burmese).

Ministry of Communications, Posts, and Telegraphs, and Korea International Cooperation Agency. 2011. Myanmar ICT Master Plan 2011-2015. Nay Pyi Taw.

Ministry of Communications, Posts and Telegraphs, Korea International Cooperation Agency and Electric and Telecommunications Research Institute. 2011. The Follow-Up Project of the Establishment of the ICT Master Plan in Myanmar. Nay Pyi Taw. 
Ministry of National Planning and Economic Development (MNPED), Swedish International Development Cooperation Agency (Sida), United Nations Children's Fund (UNICEF), and United Nations Development Program (UNDP). 2011. Integrated Household Living Conditions Survey in Myanmar (2009-2010). Yangon.

Nomura Equity Research. 2012. Asia Telecoms: Myanmar-An Untapped Telco Market. 14 March. http://www.iflr.com/pdfs/newsletters/Asia\%20Telecoms\%20-\%20Myanmar-an\%20untapped $\% 20$ telco\%20market\%20(14\%20Mar\%202012).pdf

Orbicom and International Development Research Centre. 2009. Digital Review of Asia Pacific 20092010. New Delhi: Sage Publications. http://www.digital-review.org/uploads/files/pdf/20092010/4th_edition_prelim.pdf

Paul Budde Communication. 2010. Myanmar (Burma) - Telecoms, Mobile and Internet. Lower Hunter Valley.

Ramamurthy, A. 2013. A Perspective on ICT for Development (ICT4D) Intervention Opportunities in Myanmar, Nepal and Sri Lanka.

Rieffel, L. 2012. The Myanmar Economy: Tough Choices. Global Economy and Development Working Paper 51. Washington, DC: Brookings Institution.

Smith, H. 2012. Proposed New Telecommunications Law in Myanmar: Where are the Opportunities and Risks for Japanese Investors? Intellectual Property \& Technology, Media and Telecommunications Newsletter. 19 April.

United Nations. 2012. E-Government Survey 2012: E-Government for the People. New York.

- 2014. E-Government Survey 2014: E-Government for the Future We Want. Development Database. New York.

United Nations Economic and Social Commission for Asia and the Pacific (ESCAP). 2004. Trade and Investment Policies for the Development of the Information and Communication Technology Sector of the Greater Mekong Subregion. Bangkok.

2013. An In-depth Study of Broadband Infrastructure in the ASEAN Region. Bangkok.

United Nations Statistical Institute for Asia and the Pacific. 2007. Management Statistical Development and Information Technology for National Statistical Offices (Myanmar). Country paper submitted to the Sixth Management Seminar for the Heads of National Statistical Offices in Asia and the Pacific. Hong Kong, China. 28-30 May.

Vanderbruggen, E. and K. Naing. 2012. Myanmar's Draft Law on Telecommunication: A Few Notable Issues for Foreign Investors. Yangon: VDB Loi.

World Bank. 2011. Information and Communication Technologies Sector Strategy Approach Paper. Washington, DC. 
-World Development Indicators. http://data.worldbank.org/data-catalog/world-development -indicators

World Bank and International Telecommunication Union (ITU). 2012. The Little Data Book on Information and Communication Technology 2012. Washington, DC: World Bank. 


\section{Developing Myanmar's Information and Communication Technology Sector toward Inclusive Growth}

This paper assesses Myanmar's information and communication technology sector, identifies constraints the sector faces, and recommends policies that will help the government overcome them.

\section{About the Asian Development Bank}

ADB's vision is an Asia and Pacific region free of poverty. Its mission is to help its developing member countries reduce poverty and improve the quality of life of their people. Despite the region's many successes, it remains home to the majority of the world's poor. ADB is committed to reducing poverty through inclusive economic growth, environmentally sustainable growth, and regional integration.

Based in Manila, ADB is owned by 67 members, including 48 from the region. Its main instruments for helping its developing member countries are policy dialogue, loans, equity investments, guarantees, grants, and technical assistance.

$\mathrm{ADB}$ 